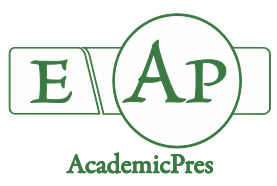

Gillani SFA et al. (2021)

Notulae Botanicae Horti Agrobotanici Cluj-Napoca

Volume 49, Issue 4, Article number 12525

DOI: $10.15835 /$ nbha49412525

Review Article

\title{
Assessment of cold stress tolerance in maize through quantitative trait locus, genome-wide association study and transcriptome analysis
}

\author{
Syed F.A. GILLANI ${ }^{1,2}$, Adnan RASHEED ${ }^{3}$, Gai YUHONG ${ }^{4}$, \\ Wei JIAN ${ }^{3}$, Wang Y. XIA ${ }^{1,2}$, Huma TARIQ \\ Muhammad ILYAS ${ }^{5}$, Peng YUNLING ${ }^{1,2 *}$
}

${ }^{1}$ Gansu Agricultural University, College of Agronomy, Lanzhou 730070, China; faheemgillani33@gmail.com; pengyunlingpyl@163.com (*corresponding author);1523875996@qq.com

${ }^{2}$ Gansu Provincial Key Lab of Arid Land Crop Science, Lanzhou 730070, China

${ }_{3}^{3}$ Jilin Changfa Modern Agricultural Science and Technology Group Co., Ltd., China; adnanrasheed@jxau.edu.cn; 148050459@qq.com

${ }^{4}$ Jilin Agricultural University, College of Agronomy, China; gyh32101@163.com

${ }^{5}$ University of Poonch Rawalakot Azad Kashmir, Laboratory of Plant Breeding and Molecular Genetic, Pakistan; huma.tariq006@hotmail.com; muhammadilyas@upr.edu.pk

\begin{abstract}
Genome-wide association study (GWAS) has become a widely accepted strategy for decoding genotype phenotype associations in many species thanks to advances in next-generation sequencing (NGS) technologies. Maize is an ideal crop for GWAS and significant progress has been made in the last decade. This review summarizes current GWAS efforts in maize functional genomics research and discusses future prospects in the omics era. The general goal of GWAS is to link genotypic variations to corresponding differences in phenotype using the most appropriate statistical model in a given population. The current review also presents perspectives for optimizing GWAS design and analysis. GWAS analysis of data from RNA, protein, and metabolite-based omics studies is discussed, along with new models and new population designs that will identify causes of phenotypic variation that have been hidden to date. The detailed that low temperature in maize seedlings altogether restricts germination and seedlings' development and destabilizes the cancer prevention agent safeguard component. Cold pressure adversely influences root morphology, photosystem II (PS II) effectiveness, chlorophyll substance, and leaf region. A short scene of low temperature stress (for example, under $10{ }^{\circ} \mathrm{C}$ for 7 days) during the V6-V9 maize development stages can fundamentally defer the anthesis commencement. Among the morphological reactions by focused on maize plants, low temperature stress causes strange tuft development in maize, along these lines influencing the fertilization and grain filling measures. Hence, problematic temperatures can cause a genuine yield decrease if happening at basic conceptive stages, as plants allocate over half of their photosynthesis to foster grains during this stage until physiological development. Low temperature stress fundamentally diminishes the plant stature and absolute yield biomass of maize. Leaf improvement turns out to be delayed in chilly focused on plants because of a drawn-out cell cycle and diminished pace of mitosis. The joint and continuous efforts of the whole community will enhance our understanding of maize quantitative traits and boost crop molecular breeding designs.
\end{abstract}

Keywords: GWAS; functional genomics; mixed model; population design; Zea mays

Received: 09 Oct 2021. Received in revised form: 04 Nov 2021. Accepted: 12 Nov 2021. Published online: 10 Dec 2021.

From Volume 49, Issue 1, 2021, Notulae Botanicae Horti Agrobotanici Cluj-Napoca journal uses article numbers in place of the traditional method of continuous pagination through the volume. The journal will continue to appear quarterly, as before, with four annual numbers. 


\section{Introduction}

In the current scenario of global climate change, the utmost desire to ensure food security is to maintain and increase agricultural production. But, due to rapid climate change, many abiotic factors such as rainfall, drought, flooding, temperature and solar radiations are severely affecting the production of cereal crops at various growth stages (Saleh et al., 2008; Saud et al., 2013; Saud et al., 2014; Saud et al., 2016; Saud et al., 2017; Sajid et al., 2019; Sajid et al., 2020; Saud et al., 2020; Unsar Naeem et al., 2020). The effects of climate change on agriculture could not be ignored. Changes in precipitation and temperature as well as the increase in $\mathrm{CO}_{2}$ levels leading to climate change have significant impacts on global agriculture. The decrease in the yield of agricultural products and the change in land structure cause people not to receive recompense for their labor and break their hopes (Shah at al., 2013; Tariq et al., 2018; Shafi et al., 2020; Senol et al., 2020; Saman et al., 2020). World population is increasing at an alarming rate and more food is needed to satisfy the hunger of human being within existing resources (Rasheed et al,, 2017; Rasheed et al., 2018; Rasheed et al., 2019; Rasheed et al., 2021a; 2021b). Maize (Zea mays L.) started in the Balsas River bowl of southwestern Mexico roughly 9000 years prior (Alam et al., 2017). It has since spread geologically and financially, becoming perhaps the main harvests worldwide for food, feed, and fuel (Alexander et al., 2009). Maize grain creation has expanded more than eight-crease in the previous century to a current yearly worldwide creation of one billion tons (An et al,, 2012). Mapping of quantitative trait loci (QTL) brought a revolutionary breakthrough in the world of crop production. Salinity, drought, water logging and toxicity are those abiotic stresses that affect the crop yield and production (Wajid et al., 2017; Saman et al., 2020; Wahid et al., 2020). Notwithstanding, ceaselessly enhancing requests for maize creation has prompted the nonstop requirement for hereditary improvement of different agronomically and monetarily significant attributes (Anders et al., 2015). The most monetarily significant attributes are generally acquired in a quantitative way, and the hereditary premise is ascribed to polygenes and cooperation impacts among qualities and additionally qualities and the climate (Apel et al,, 2004). Linkage planning dependent on an isolating populace from a cross between two guardians showing maximally various aggregates is a notable way to deal with find quantitative attribute loci (QTL) (Applequist et al., 2001).

They are measurably gathered, for the most part through direct relapse and most extreme probability gauge techniques, and in light of a hereditary linkage map (Ardy et al., 2002). A couple of QTLs are by and large distinguished by means of linkage planning in each trial (Atwell et al, 2010). Further fine planning of QTL to an all the more barely exact hereditary position and cloning of the basic quality, as huge optional populaces are by and large needed to accomplish adequate guide goal (Atwell et al., 2010; Ayers et al., 2010). The huge and complex maize genome, over $85 \%$ of which comprises of dull groupings further eases back progress in QTL fine planning and cloning. Genome-wide affiliation study (GWAS) utilizing assorted populaces gives another technique to successfully fine guide QTL because of an enormous number of authentic recombination occasions that lead to the fast rot of linkage disequilibrium (Bajželj et al., 2014). In general QTL mapping provides the opportunity to detect and clone the QTL of major traits in crops (Rasheed et al., 2020a; 2020b; 2020c).

This affiliation planning methodology was initially applied in plants in the start of the $21^{\text {st }}$ century as an up-and-comer quality affiliation (Ardy et al., 2002). Concentrate in maize nonetheless, the principal affiliation learn at genome-wide scale was accounted for in maize, in 2008, in which 8590 loci in 553 world class maize inbreeds was utilized to investigate the qualities influencing unsaturated fat content in bits (Bano et al., 2015). Right now, GWAS is an everyday practice instrument in the investigation of human illness and other complex attributes in numerous enormous accomplice examinations (Barnabás et al., 2008). For maize, since the arrival of the B73 reference genome (Bates et al., 2015). GWAS has multiplied significantly and many agronomically significant characteristics have been analyzed (Bilska-Kos et al., 2017) (Figure 1). 


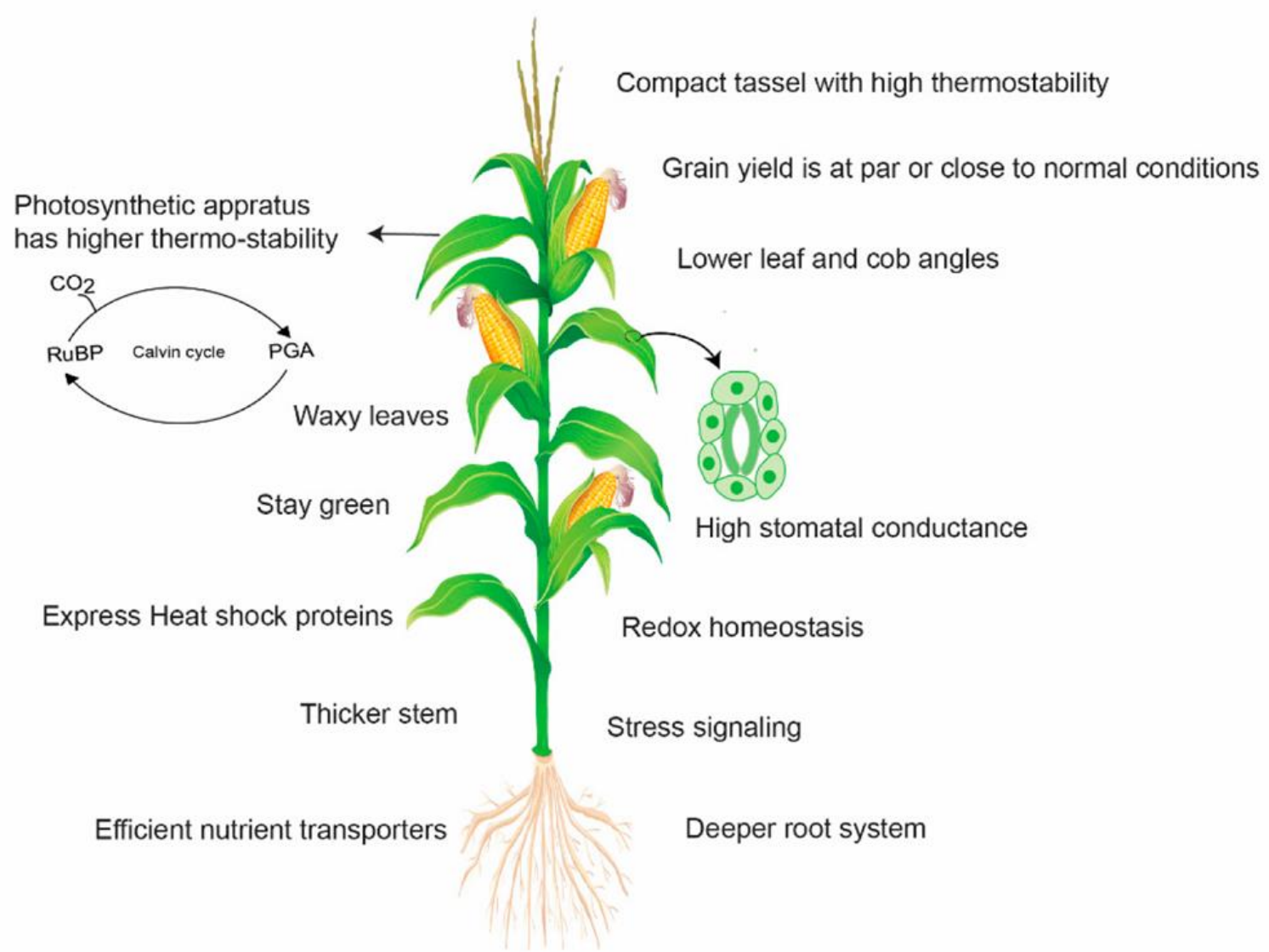

Figure 1. Basic mechanism evolved during cold stress in maize plant.

These advances recommend GWAS is an amazing asset to viably and effectively distinguish genomeaggregate affiliations (Boehlein et al., 2019). In this survey, we

- Audit maize practical genomics worked with by GWAS on agent attributes and a huge scope (Cai et al., 2017).

- Diagram progress of new hereditary and more elevated level (over-hereditary) variety, strategy advancements, and populace plans that boost factual force (Cárcova et al., 2001).

- Talk about the difficulties and openings for maize GWAS in the future (Change et al., 2007).

Functional genomics in plants intends to distinguish the capacities of all qualities (Chen et al., 2007). Somewhat recently, the unstable turn of events of cutting-edge sequencing (NGS) advancements, and the arrival of the maize B73 reference genome, have generally advanced maize hereditary examination into the genomics period (Chen et al, 2012). Until now, different characteristics, going from sub-atomic (counting the transcriptome) to cell (i.e., metabolites), and from the individual morphological scale (agronomic, yield, or conceptive qualities) to the collaboration with various ecological variables (biotic or abiotic stress resistance), have been thoroughly examined, alongside (Cho et al., 2010).various cloned qualities and a lot more proposed quality contender for comparing attributes, all utilizing a GWAS approach (Cicchino et al., 2010). GWAS Helps Understand Genetic Architecture of Complex Quantitative Traits Exceptionally enormous scope GWAS examinations give new freedoms to comprehend the hereditary engineering of complex quantitative attributes (Commuri et al., 2001). 


\section{GWAS: a promising tool in maize functional genomics}

The information produced to date for the most part show that a huge number of QTL are being distinguished yet each just clarifies a little piece of phenotypic variety for the greater part of the agronomic characteristics examined in maize (Deeks et al., 2012). For instance, in excess of 40 QTL were planned for blossoming time (Dubouzet et al., 2003). Expanding Number of Publications on Maize GWAS since the Release of the B73 Reference Genome (Edreira et al., 2011). Then again, cell quality and piece organization characteristics seem to have a less muddled hereditary design, with a more modest number of bigger impact QTL to be recognized (Esim et al., 2016). In one examination, a few qualities were found to clarify over $10 \%$ of the difference for bit oil fixation (Fang et al., 2020). In another investigation, the related loci were discovered that clarify more than $20 \%$ of noticed change in the auxiliary metabolomics attributes of maize bits, with a middle of 7.8\% (Fang et al., 2017). GWAS on transcriptomic variety, likewise called articulation QTL (eQTL) planning, joins hereditary markers to articulation variety from a huge number of qualities, and has exhibited the simplex hereditary reason for quality articulation characteristics, as each eQTL regularly clarifies an enormous extent of phenotypic (articulation level) variety (Fang et al., 2015).

In a new report, the statement of 14375 qualities was estimated, and a normal of more than $15 \%$ of the difference was clarified for every quality per eQTL (Farooq et al., 2008). Especially, a solitary QTL was recognized for clarifying $87.7 \%$ of quality expressional fluctuation (Farooq et al, 2009). As the quality under examination travels through distinctive omic layers from the aggregate estimated in factor conditions (Foyer et al., 2002) to the degree of metabolites in single cell types, or to the outflow of single qualities (Fujino et al,, 2010). It is normal that the number of QTL distinguished will move from profoundly quantitative to subjective or single locus (Fujino et al., 2011). An expanding number of openly accessible GWAS results give the chance to limit relationship to single (Fujino et al., 2004). Very much explained competitor qualities and to comprehend genome structure and constitution related with every attribute of interest (Hernández et al., 2005). Early endeavors to ascertain the dissemination example of related loci at the genome-wide level tracked down those genic and almost genic districts (rather than intergenic areas) contribute most to maize attribute variety, particularly in the 50 UTR (Golub et al., 2016).

Besides, non-equivalent transformed single nucleotide polymorphisms (SNPs) are the most practically enhanced, along with huge duplicate number variations (CNVs), while intergenic districts show critical consumption for utilitarian SNPs (Gourdji et al., 2013). These precise investigations propose that quality guideline in articulation level should assume a critical part in phenotypic variety (Gu et al., 2013). Under this speculation, the articulation scene of youthful maize parts has been widely investigated (Guan et al., 2012) and the equivalent ends were reached as past discoveries on quantitative qualities; i.e., that non-equivalent SNPs are the hugest drivers of articulation guideline, with a higher number of SNP QTL affiliations (Han et al., 2008).

To investigate another significant layer forming hereditary variety in maize (Hartmann et al., 2000). Played out a metabolome-based GWAS in maize parts to represent the entire biochemical scene, looking for general and explicit patterns (Hasanuzzaman et al., 2020). This sub-atomic level affiliation considers enjoy taken full benefits of accessible GWAS information, which help to comprehend the inborn practical genome basic attribute variety (Hayashi et al., 2016). The subsequent deductions are fit for directing new or more inside and out quality distinguishing proof investigations (Hayashi et al., 2015). For instance, QTL results from the metabolite study and agronomic characteristics estimated on a similar populace were mutually dissected (Hepworth et al., 2002). This permitted the recognizable proof of a significant QTL influencing both the metabolic characteristic (on which it had a major impact) and the agronomic quality (on which it had a minor impact) (Hieke et al., 2014). Utilizing the hint gave by the metabolic quality as an extension prompted the distinguishing proof of a quality hidden the QTL influencing the agronomic quality, and to a superior comprehension of the basic component (Hoggart et al., 2008). When known metabolites are related with 
obscure qualities or the other way around, great hints are accommodated novel explanations of both metabolites and qualities (Hu et al., 2019).

Complex metabolic organizations can be additionally recreated or recognized as significant for a given characteristic by consolidating linkage or affiliation planning and organizations including articulation administrative networks (Huang et al., 2017) and known metabolic pathways (Huang et al., 2009). Joining huge datasets accumulated utilizing a wide range of conventions, particularly arising omics instruments, with high-throughput attribute affiliation examinations will accordingly speed maize useful genomic study (Huang et al., 2012). An early fruitful and commonsense affiliation model is the provitamin a bio fortification of maize (Hund et al, 2007). Right now, more than 250000 youngsters experience the ill effects of visual impairment every year because of nutrient An inadequacy (VAD), and almost two billion individuals, generally in nonindustrial nations, stay in danger for inadequacies for this and different micronutrients (Hunter et al., 2017). Uncommon great alleles of $\mathrm{LcyE}$ and crtRB1 were distinguished in applicant quality affiliation investigations (Hussain et al., 2018).

By introgression these uncommon alleles into first class maize germplasm through sub-atomic marker helped reproducing, maize with improved levels of supportive of nutrient (Hussain et al, 2019). A currently devoured by several thousands of African youngsters who might profit promptly, and accordingly the commonness of VAD is declining (Hussain et al, 2019). It is one of the best sub-atomic reproducing undertakings of the Worldwide Maize Program of the International Maize and Wcold Improvement Center (CIMMYT) until this point in time (Hussain et al., 2019). The streamlining of photoperiod affectability is one key factor that permits plants to adjust to new conditions in various scopes. The quality ZmCCT majorly affects photoperiod affectability furthermore, has been obviously analyzed in two free GWAS distributions (Hussain et al., 2006). The CACTA-like transposable component in the 50 UTR locale of ZmCCT is the causal variation for the methylation level of the advertiser locale (Izaurralde et al., 2011). One allele lessens quality articulation, which advances early blooming, permitting maize to fill adaptively in higher scopes. Streamlining plant design is right now one of the key targets in maize reproducing (Kang et al., 2008).

This incorporates upgrading tallness to decrease dwelling and to permit an expansion in plant thickness (Kawahara et al., 2016). Brachytic2 has been recognized as a serious, uncommon, and regular freak influencing plant stature (Koseki et al., 2010). An uncommon and regular transformation that decently decreased plant tallness has end up being the causal variation (Kovach et al., 2007). This is a new change, and is just distinguished in mild maize germplasm, which will make it simpler to figure it out its potential for yield improvement in future reproducing programs (Kuroki et al, 2007). A different report distinguished the lg1 and lg2 loci, which were discovered to be essentially connected with upper leaf point, which related to an increment in the effectiveness of sun powered radiation catch. This effectiveness gave the lg2 allele possibilities to essentially expand grain yield (Lei et al., 2014).

At long last, a 3-Kb intergenic grouping inside the KRN4 locus was discovered to be answerable for maize piece column number (KRN) variety by managing the statement of the SBP-box quality Unbranched3(Lesk et al., 2016). The ideal allele of KRN4 has been demonstrated to be essentially enhanced in world class mild inbreeds yet not in tropical maize germplasm (Li et al., 2015). Dry spell resilience is an especially intricate quantitative quality constrained by numerous loci with little impacts ( $\mathrm{Li}$ et al., 2019). It is exceptionally impacted by the climate, and is hence viewed as hard to take apart utilizing GWAS (Li et al., 2019). A progression of specialists worked on the dry spell aggregate by estimating a part attribute, seedling endurance rate submerged focused on condition, and a progression of affiliation examines distinguished positive normal variations of various qualities that could be utilized for dry spell resilience improvement in maize (Li et al., 2014). 


\section{GWAS helps understand genetic architecture of complex quantitative traits}

Diminishing characteristic intricacy by correctly estimating connected metabolic qualities rather than yield itself under dry spell has moreover prompted effective GWAS analyzation of dry season related attributes in maize (Li et al., 2014). In rundown, these and lot later outcomes summed up have permitted point by point investigation of explicit attributes of revenue (Li et al., 2011). These examinations have end up being genuinely fast and direct on the grounds that the recognizable proof of the best great alleles effectively present in regular populaces (Liu et al., 2012). Furthermore, these GWAS examines cleared the way for the most productive abuse of this regular variety, as found in the model from the crtRB1 investigation of supportive of nutrient $\mathrm{A}$ (Liu et al., 2000). Linkage examination had recognized one QTL covering the crtRB1 district in two autonomous isolating populations with comparable phenotypic variety clarified. Further quality-based affiliation investigation recognized six normal haplotypes inside crtRB1, each with various impacts (Liu et al., 2016) (Table 1).

Table 1. Inbred association panel

\begin{tabular}{|c|c|c|c|}
\hline Phenotype & Population & Sample size & No. marker \\
\hline Water tolerance & IAP & 350 & $56 \mathrm{~K}$ \\
\hline Cold tolerance & IAP & 125 & $56 \mathrm{~K}$ \\
\hline & IAP & 375 & $56 \mathrm{~K}$ \\
\hline & Dent + Flint & $306+292$ & $50 \mathrm{~K}$ \\
\hline
\end{tabular}

The affiliation data permitted the recognizable proof of potential guardians containing the specific haplotypes that ought to be crossed for maximal articulation of the quality (Liu et al., 2016). This was functional regardless of the way that the best blend of guardians came from various affiliation boards what's more, reproducing pools, and may never have been crossed without the genomic data acquired by GWAS, accordingly demonstrating the capacity to give immediate and solid data to picking suitable guardians or potentially benefactors for rearing. In the previous few decades, GWAS has effectively distinguished great many related loci in people, creatures, and plants (Lizaso et al., 2018), this has given numerous advantageous signs to further develop sickness treatments and creature or potentially crop rearing (Lobell et al., 2011). Nonetheless, just a little part of phenotypic variety for a characteristic can be clarified in some random GWAS, particularly in human investigations, raising a drawn-out banter over the issue of "missing heritability (Long et al., 2010).

For instance, GWAS has recognized many human tallness related loci in a huge human accomplice informational collection, yet they just represented a little part (<5\%) of absolute heritability (Lu et al., 2014). On the other hand, by utilizing all genome-wide SNPs in an examination (not simply measurably huge SNPs), all things considered expanded the gauge of tallness heritability to $67 \%$ through an exemplary quantitative hereditary methodology (Lü et al., 2011). These outcomes give an update that heritability may stay stowed away in genomics concentrates until the appropriate apparatuses can uncover the missing part (Lukatkin et al., 2003). This part is accepted to be mostly available through the investigation of variations in qualities of minor impact in more hereditarily homogeneous foundations, by expanding variations present in populaces at low recurrence until their impact can be appropriately estimated, or by including new hereditary variations undiscovered in past investigations (Lv et al., 2020: Ibrar et al., 2020) (Figure 2). 


\section{A}

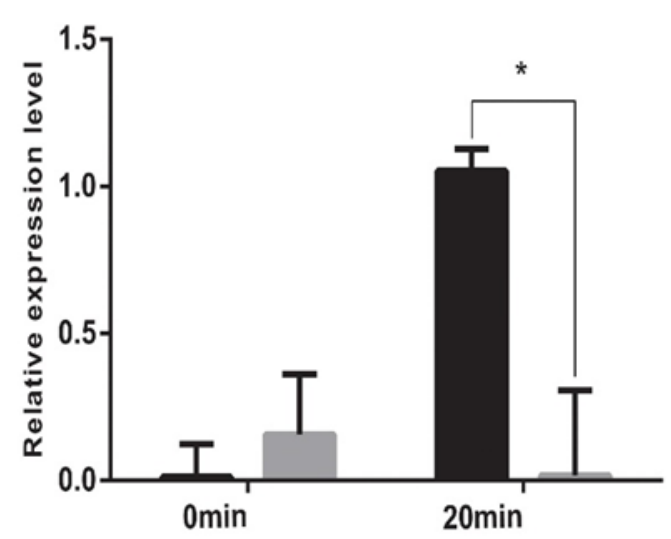

resistance
susceptibility

B

OSDREB1C

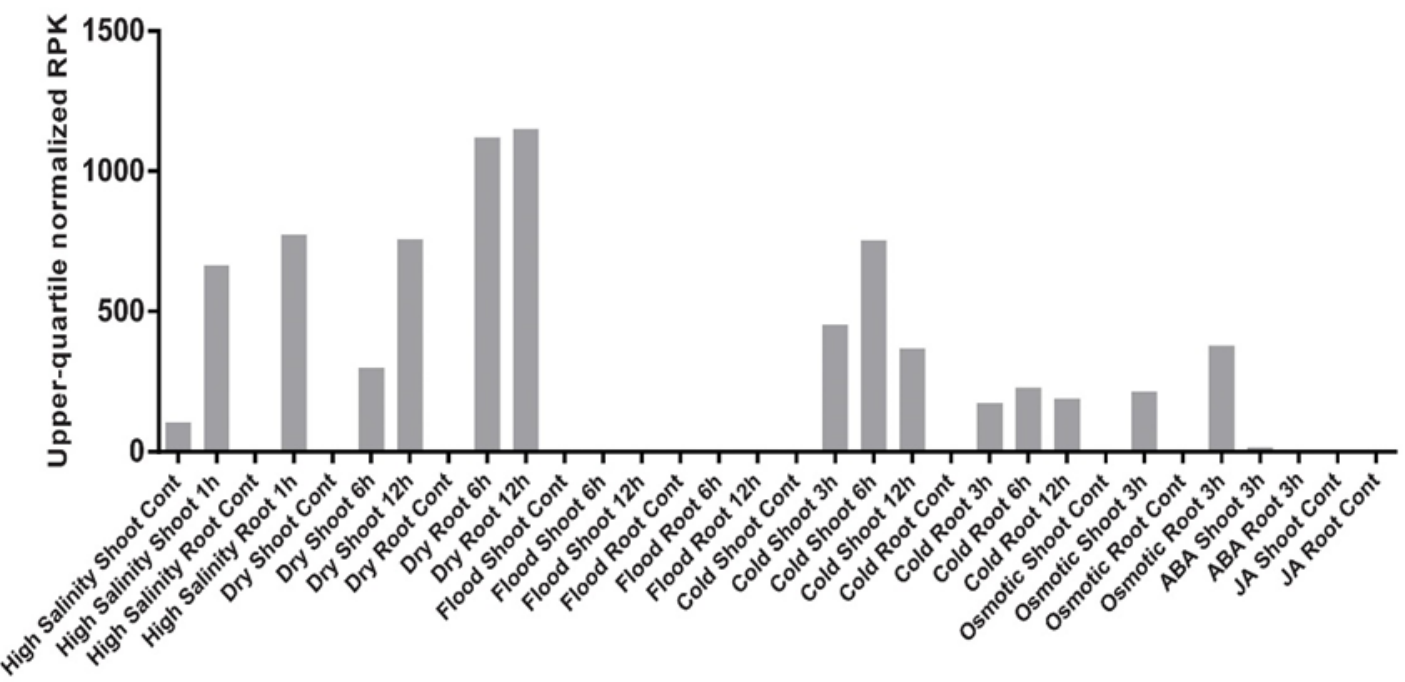

Condition

Figure 2. GWAS results showed the response of maize plant under various stress conditions

A significant distinction between plant and human frameworks is that controlled intersection tests are conceivable in the previous yet not in the last mentioned (Ma et al., 2018), henceforth, plant frameworks give a doable chance to work with GWAS in intricate populace or measurable plans to improve planning power (Ma et al., 2015). In the following segments, we sum up three conceivably free methodologies that, independently or mutually, may add to uncovering missing heritability in plants, particularly in maize, including novel kinds of genotypes furthermore, aggregates, measurable technique advancements, and new hereditary plans (Mao et al., 2015).

It was recognized more than 1,000,000 PAVs by planning 26 million labels from 14129 innate lines, and tracked down that this kind of variety displays advanced relationship with a wide scope of phenotypic characteristics (Michaels et al., 2018). The PAVs of translated successions were to a great extent associated with articulation guideline, metabolic vacillation, also, more elevated levels of phenotypic variety and heterotic (Morell et al., 2001). These major underlying improvements, including considerably bigger scope redundancies brought about by transposable components, are known to represent enormous rates of the (Moser et al., 2015), substance inside the maize genome and may assume bigger parts in making phenotypic variety than singlenucleotide variations (SNVs); nonetheless, in light of the fact that a significant number of the bigger scope 
changes are in high LD with flanking SNV, it is hard to appoint the phenotypic changes to either solely (Nazir et al., 2020).

Higher-request or over-genomic varieties, for example, changes or contrasts in articulation levels, have end up being extraordinary assets as "sub-atomic aggregates" (Neiff et al., 2016). Along these lines, we recommend that they could likewise be viewed as free "sub-atomic genotypes" that are not basically in LD with genomic variety. It utilized articulation PAV as the "genotype" and tracked down this sort of marker playing huge jobs in articulation guideline, metabolome variety, also, morphological characteristic variety. By changing articulation level into double variety, (Neild et al., 2009), utilized high versus low articulation (comparative with the middle worth) as variety to uncover the commitment of differentially communicated qualities to their comparing cell and agronomic characteristic fluctuation (Panison et al., 2016) (Table 2).

Table 2. Performance comparison of different methods in mixed linear model GWAS

\begin{tabular}{|c|c|c|c|c|c|c|c|}
\hline \multirow[b]{2}{*}{ Year } & \multirow[b]{2}{*}{ Method } & \multirow{2}{*}{$\begin{array}{c}\text { Positive } \\
\text { semidefinite } \\
\text { matrix } \\
\text { requirement }\end{array}$} & \multicolumn{3}{|c|}{$\begin{array}{l}\text { Strategy for increasing computational } \\
\text { speed }\end{array}$} & \multirow[b]{2}{*}{$\begin{array}{l}\text { Computational } \\
\text { speed }\end{array}$} & \multirow[b]{2}{*}{ Statistical power } \\
\hline & & & $\begin{array}{c}\text { Approximate/ } \\
\text { Two-step } \\
\text { approach }\end{array}$ & $\begin{array}{l}\text { Matrix } \\
\text { optimiz } \\
\text { ation }\end{array}$ & $\begin{array}{l}\text { Low-rank } \\
\text { matrix }\end{array}$ & & \\
\hline 2006 & Standard MLM & & & & & Low & High \\
\hline 2007 & GRAMMAR & & + & & & Very fast & Intermediate \\
\hline 2008 & EMMA & + & & + & & Intermediate & High \\
\hline 2010 & EMMAX & + & + & + & & Fast & $\begin{array}{c}\text { High/ } \\
\text { Intermediate }\end{array}$ \\
\hline 2010 & P3D,M CMLM & & + & & + & Fast & $\begin{array}{c}\text { High/ } \\
\text { Intermediate }\end{array}$ \\
\hline 2011 & FaST-LMM & + & & + & & Fast & High \\
\hline 2012 & GEMMA & + & & + & & Fast & High \\
\hline 2012 & $\begin{array}{l}\text { FaST-LMM- } \\
\text { Select }\end{array}$ & + & & + & + & Very fast & High \\
\hline 2014 & ECMLM & & + & & + & & $\begin{array}{c}\text { High/ } \\
\text { Intermediate }\end{array}$ \\
\hline 2014 & SUPER & + & & + & + & Fast & High \\
\hline 2014 & & & & & & & \\
\hline
\end{tabular}

Results demonstrate that transcriptomic variety is predominant and works at the administrative level (Paterson et al., 2013), and show a few benefits that are integral with SNP-characteristic affiliation contemplates: (1) they reflect variety in both hereditary and epigenetic administrative components; (2) they give extra proof to fine guide QTL; (3) they help to comprehend sub-atomic systems and develop administrative organizations (Paterson et al., 2003). Sub-atomic aggregates over the genome level would now be able to be immediately estimated with high-throughput and minimal expense stages, and can be utilized on one or the other side of the planning condition (Pertea et al., 2016) this could fill in missing data when at least one factors were thought about reciprocally. The epigenomic code gives another basic layer in choosing the destiny of a cell or a life form. Epigenetic changes can be autonomous from genomic variety and react (in vivo and in vitro) to climate changes, going with phenotypic inconstancy (Piepho et al., 2007).

Ongoing advances in populace epigenomics in a small bunch of animal types have zeroed in on unraveling the hereditary premise, actually in regards to the epigenetic adjustment as "attributes" (Pugh et al., 2010). With respect to epigenome as the "genotypic" side of the condition would be important, like the transcriptome examined above, and, along with other omics investigations of the proteome and metabolome, this sort of over-genomic variety could be applied as sub-atomic markers to analyze downstream aggregates. Since the epigenome and transcriptome are nearer to their phenotypic results than the genome does, they additionally hold the guarantee of recovering missing heritability. The recognizable proof of varieties in these 
new "genotypes" at the populace level for species with enormous genomes like maize, at present is still nontrivial, as it doesn't think about tissue and formative stage contrasts (Qin et al., 2008).

Besides, as various as genomic varieties with paired or restricted quantities of alleles can be, variety for new omics qualities are quantitative and range alterable, along these lines making traditional and clear planning strategies inadmissible for new omics information (Rafique et al., 2019). It was recommended a minimal expense catch based bisulfite approach for powerfully and dependably breaking down DNA methylation for pre-characterized genomic areas. It was proposed a contingent Gaussian Bayesian strategy to derive conceivable connections between discrete what's more, consistent qualities under an organization technique, which might be promising for affiliation planning also (Raza et al., 2019). A direct relapse model representing populace design and relatedness grid while breaking down more elevated level omics information, quantitative GWAS (qGWAS), has as of late been proposed to tackle the constant genotype issue, and has been utilized to investigate the administrative organization (Read et al., 2001).

Future advancements in sequencing advances ought to be thought about correspondingly with new logical strategies centered on more significant level variety to all the more completely enlighten the covered-up secrets at the most minimal omics levels (Reeves et al., 2001). Inventive GWAS METHODS IMPROVE Planning POWER To evaluate how qualities or QTL impact phenotypic variety, early GWAS essentially relapsed the marker variable against the aggregate, and furthermore utilized control foundation commotion with covariates to preclude bogus relationship due exclusively to populace structure in normal populaces of plants (Riva-Roveda et al., 2016). Nonetheless, in a characteristic populace, the people consistently share complex tribal relatedness, generally due to broad intercrossing endeavors in crop rearing (Robinson et al., 2010). The one-measurement size of induced subpopulations for GWAS is for the most part deficient to control the covariance connections between individual combines in multi-dimensional scales, also, the degree of inclination relies upon the quality fundamentally (Ruan et al., 2013).

In animal breeding programs, the blended model methodology is regularly used to choose great people in a rearing populace in light of rearing qualities, assessed utilizing a family based hereditary relatedness network (GRM) between individual sets of creatures (Ruan et al., 2005). Although apparently clear (Rymen et al., 2007). It is infeasible to straightforwardly apply the creature blended model to plant GWAS, in light of the fact that harvest rearing family records are at times erroneous and regularly totally obscure. A brought together blended model technique that substitutes the inaccessible family based GRM with a marker-based GRM was an effective answer for all the while represent populace structure and the difference covariance lattice in GWAS (Saito et al., 2010) (Figure 3).

In the accompanying segment, we call this the standard Mixed Linear Model (MLM) strategy (Saito et al., 2004) and we sum up key focuses and inspirations of late enhancements in GWAS strategies. Variety of Mixed Models for Improving GWAS Power Measurably talking, it is direct to further develop power by means of expanding test size. Notwithstanding, the standard MLM technique is wasteful for huge informational indexes (those with a huge number of people), in view of the computational weight important for mathematical streamlining (Sánchez et al., 2014). In a first endeavor to work on the speed of GWAS estimations, the productive blended model affiliation (EMMA) technique improves on network tasks through ghastly decay (Sandhu et al, 2018). Be that as it may, this "accurate technique" of tackling blended model conditions with entire genome markers in an iterative style is of restricted esteem when testing a large number of markers to recognize all recombination occasions. Other assorted new strategies with various suppositions have been proposed for investigation with persistently expanding test size and marker thickness, and subtleties of these new strategies are momentarily presented underneath (Sang et al., 2007).

A decent compromise between computational speed and factual force can be made by just assessing model boundaries once and then, at that point continually testing markers iteratively utilizing a rough strategy, commonly including the P3D (populace boundary recently resolved) and the remaining methodology. The P3D approach, counting P3D (Schauberger et al., 2017) gives comparable advantages to the remaining methodology, (for example, genome-wide fast affiliation utilizing blended model and relapse (Segura et al., 
2012) nonetheless, the P3D and lingering approaches are actually unique. The lingering approach fits the residuals from a decreased blended model as the reliant variable to test marker importance utilizing a straight relapse, though P3D fits the unique aggregate as the reliant variable and tests marker importance under a blended model in with fixed difference boundaries got from the decreased model (Shen et al., 2007).
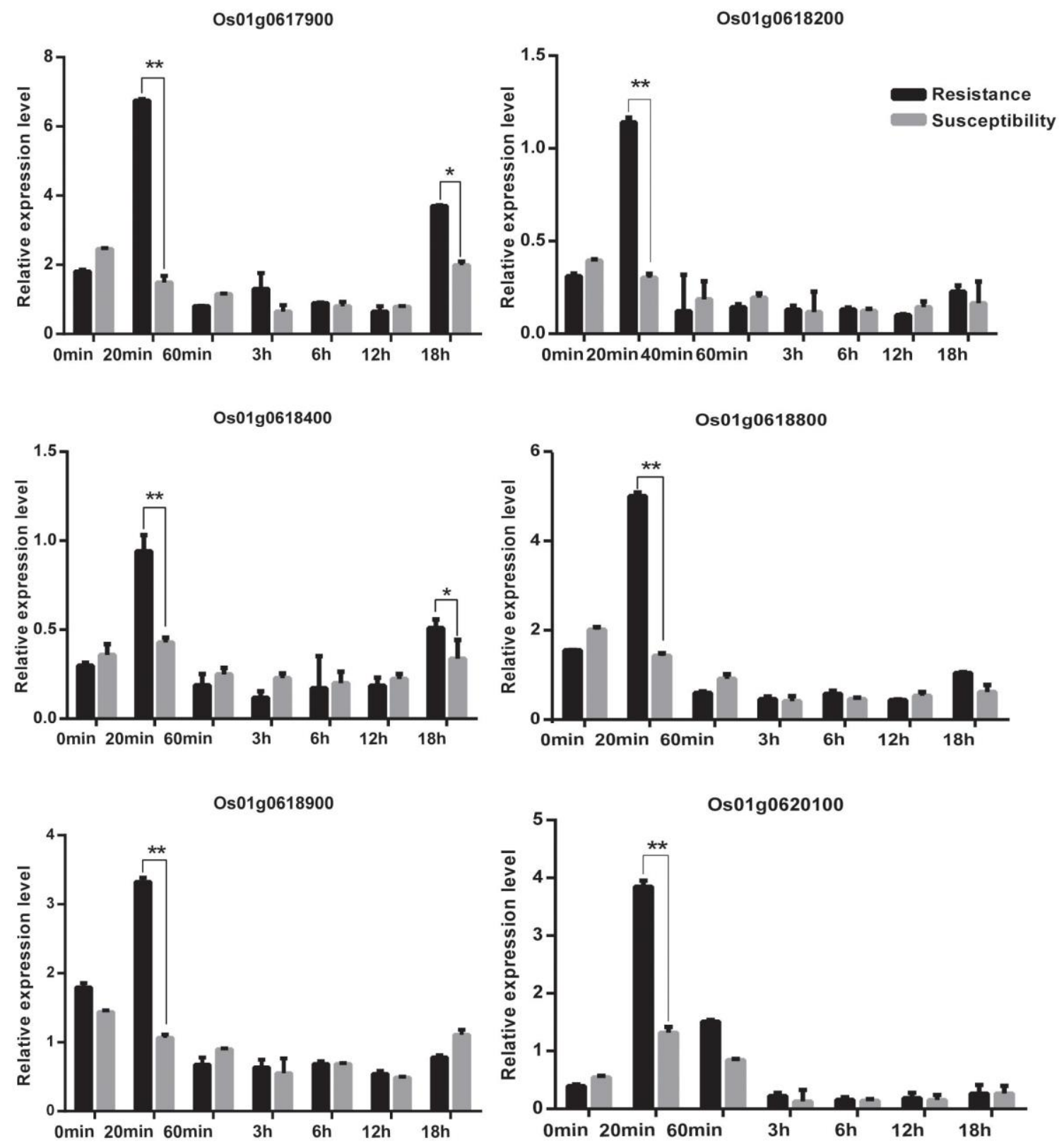

Figure 3. Expression pattern of different genes under cold stress in maize

\section{GWAS on molecular phenotypes yields genome annotation and insights into mechanisms}

Accepting polygenic legacy, rough techniques have end up being a productive answer for accelerate GWAS for large scale informational indexes meaning to expand planning power. In truth, be that as it may, it's anything but conceivable to know deduced how exact the estimated techniques will be (Shim et al., 2017). Two free calculations were proposed to work on the speed of the specific strategy by improvement of the blended model condition, and these are named the calculated frightfully changed straight blended model (FaST-LMM) 
(Siebers et al., 2017) and the genome-wide productive blended model affiliation (GEMMA) calculation (Song et al., 2017). Momentarily, the worked on precise techniques regularly center around modifying the mixed model conditions that refactor the customary probability work of the blended model to a structure comparable to the probability of a direct relapse model. This advancement improves on the multidimensional boundaries assessment into a one-dimensional mathematical enhancement issue, significantly lessening computational weight for every cycle (Steward et al., 2018).

These techniques work at even more prominent rates than the surmised strategies in enormous scope GWAS. To tackle a blended model condition, figuring cost is expanded generally because of the network tasks that gauge arbitrary impacts, which are corresponding to the cubed test size. Thus, it ought to be feasible to additionally further develop GWAS speed by utilizing a low-position framework in the blended model. In creature reproducing, creatures' rearing worth can be anticipated by their sire beginnings; consequently, creature connections can be assessed by sire covariance lattices (this is named the family-based sire model). Also, (Su et al., 2016) initially proposed a low-position network based blended model approach, which they called the packed MLM (CMLM). This model uses the GRM between sets of gatherings to supplant the GRM between sets of people as the irregular impact. The CMLM technique was additionally streamlined by including another boundary to characterize calculations for computing GRM between gatherings, named enhanced CMLM (ECMLM) (Suh et al., 2010).

On the other hand, (Sun et al., 2018) represent an extraordinary failure rank framework strategy inside Quick LMM, which actually manages an individual-sets GRM grid, however, to appraise it utilizing a lot more modest subset of markers rather than by utilizing every one of them (Sun et al., 2017). The best markers to assess the low-position GSM framework has not however been resolved. Under the supposition of the blended model comparable to a Bayesian direct relapse model, the all-encompassing form of FaST-LMM calculation, FaST-LMM-Select, endeavors to pick the best markers relying upon the affiliations with a normal characteristic (Sun et al., 2013).

Momentarily, direct relapse is first and foremost led to arrange all markers rising by $\mathrm{p}$ esteems; the ideal subset of compelling markers is then controlled by searching for least genomic control file esteem, a boundary to appraise the genomic swellings because of foundation commotion, which is ordinarily utilized in human infection GWAS contemplates (Tamura et al., 2011). For each tried marker, the GSM network is iteratively set up by utilizing distinguished persuasive markers previously precluding the tried markers (and all markers inside $2 \mathrm{cM}$ ) (Tao et al., 2007). Past FaST-LMM-Select, a comparative in any case, more modern calculation, called Settlement of MLM under Progressively Exclusive Relationship (SUPER), gives another arrangement by treating the number and content of powerful markers as hereditary boundaries of blended model capacities for explicit attributes.

Streamlining of the probability would then be required to increment factual power and lessen bogus positives (Tao et al., 2012). New GWAS Methods for Multi-variation Test of Rare Variations Customary GWAS techniques, including those referenced previously, accept the normal illness brought about by normal variations model (CDCV) (Tao et al., 2016). Due to this predisposition, and since uncommon variations have such low measurable force, it is common to sift through uncommon variations before any GWAS. Be that as it may, uncommon alleles might be the reason for the phenotypic variation of interest. Along these lines, this is one wellspring of the missing heritability, in light of the fact that an absence of adequate force won't permit distinguishing proof of uncommon causal variations except if their impact on the aggregate is very enormous (Thakur et al., 2010).

Also, the instance of different uncommon utilitarian variations in close by positions can conceivably trigger circuitous affiliations (engineered affiliation); these might be in places that are mega bases away from utilitarian variations (Thompson et al, 2007). Manufactured affiliations brought about by long-range LD blocks cause low GWAS goal also, increment hardships in pinpointing causal qualities dependent on GWAS signals (Tian et al., 2017). In species filled in extremely enormous numbers, as of late arose uncommon 
variations were found to be exceptionally pervasive, and hence naturally accepted to play fundamental capacities on attribute varieties this was shown exactly to be valid (Tian et al., 2019).

More vigorous proof will follow as genotyping advancements quickly advance, which empowers a more complete appraisal of uncommon variations with particularly enormous example sizes and their jobs in complex qualities (Tominaga et al., 2008). At the point when at least two free causal variations, each with immaterial impact, existing together in an acquired area (e.g., recombinant receptacle or LD block), it is genuinely farfetched that any single variation will be identified, however would be feasible to be distinguished by mutually testing the variations collectively in a multi-variation test (Ummenhofer et al., 2017). Multi-variation techniques, which profit with uncommon variation discovery requests (and possibly stay away from manufactured affiliations), are presently accessible to address various unlinked causal variations, and have been checked.

These techniques expect either fixed or irregular impacts. On the premise of fixed-impact supposition for tried variations, trouble tests propose the data from multi-variations are fallen into a new measurable score that tests the relationship between the score also, an attribute (Vos et al., 2005). For the premise of arbitrary suspicion, variance component tests have been proposed, and blended models are used to test the probability proportion for a gathering of multi-variations treated as irregular impact factors with free typical dispersions. Another choice to examine connected free causal variations is the haplotype-based affiliation examination. This halfway resolves the issue of manufactured affiliation by means of the distinguishing proof of the meaning of allelic series or hereditary heterogeneity ascribed to numerous utilitarian polymorphisms in a genomic (or gene based) locale (Wang et al., 2017).

\section{GWAS success in enhancing maize breeding by identifying beneficial alleles}

Environmental change is compromising food security across the globe Alam et al. (2017). Harvest yield should increment by $25-70 \%$ continuously 2050 without squeezing biological system working (Alexander et al., 2009; An et al., 2012). Since the 1960s, the yield improvement pace of significant food crops (rice, and maize) has eased back down (Anders et al, 2015), and current yield patterns are not adequate to meet future necessities (Apel et al., 2004). Also, enhancements in crop usefulness should be achievable in a profoundly irregular environment. More and strengthened limit climatic occasions (dry spell, cold wave, ice, hefty precipitation, storms, and so forth) are expected in the future (Applequist et al., 2001; Ardy et al., 2002). These uncommon climatic limits will contrarily impact plant development and improvement, environment administrations, and human solace (Atwell et al., 2010). Maize (Zea mays L.) crop gives $19.5 \%$ of worldwide caloric admission from all sources (Atwell et al,, 2010; Ayers et al., 2010). Moreover, it has additionally become a significant mechanical item. Notwithstanding, temperature limits (event of high and low temperatures during the development time frame) are compromising the yield supportability of maize. Maize plants are delicate to warm pressure $\left(>30^{\circ} \mathrm{C}\right)$ and there is a solid decrease in grain yield as plants face cold pressure over this limit for a delayed span (Bajželj et al., 2014).

The ideal development of maize crop needs unique temperatures during day and night and over the entire developing season. During sunlight, the ideal temperature shifts from 25 to $33^{\circ} \mathrm{C}$, though during the evening, ideal temperature differs from 17 to $23^{\circ} \mathrm{C}$; the mean ideal temperature for the entire developing season is $20-22^{\circ} \mathrm{C}$ (Bano et al., 2015). Maize plants sprout best at $25-28^{\circ} \mathrm{C}$ (Barnabás et al., 2008). The conceptive stage is the touchiest to imperfect and supra-ideal temperatures. A swing from the ideal temperature causing high-temperature stress essentially diminishes the development rate and grain yield through a decline in seed setting proportion and unsettling influence of a few physiological cycles. The base and most extreme edge temperatures at different development and formative phases of maize crop. It is extended that until 2050, 45\% of the worldwide maize creation region is probably going to confront a mean scene of five days of the greatest temperature $>35^{\circ} \mathrm{C}$ during the regenerative stage yearly (Bates et al., 2015). 
This is essential to note as a simple $1{ }^{\circ} \mathrm{C}$ ascend in mean occasional temperature can cut the monetary yield of maize crop by 3-13\% (Bilska-Kos et al, 2017). A high temperature at basic advancement stages may likewise weaken the nature of maize grains (Boehlein et al., 2019). Diminished seed setting in summer maize (ZD958 planted in Hebei, China, in 2018) presented to warm pressure at the fertilization stage. The temperature surpassed $35^{\circ} \mathrm{C}$ at the hour of dust shed, influencing the dust gathering by at first arose silks at the foundation of the ear when contrasted with the tip of the ear for late-arising silks. Despite the fact that maize crop is initially from the (sub-) jungles, its development has moved to areas with mild environments. Efficiency misfortune under low temperature principally happens in view of a solid decrease in metabolite transport and photosynthetic movement (Sandhu et al., 2018). As a general rule, low temperature adversely influences vaporous trade, water use proficiency, morphology, and physiology (Pertea et al., 2016, Reeves et al., 2001). Ranchers sow maize right on time to get away from cold pressure at the regenerative stage, yet plants are presented to low soil temperature (under $10^{\circ} \mathrm{C}$ ) during early seedling foundation.

During this stage, soil temperature firmly impacts leaf improvement as the shoot zenith is situated extremely close to the dirt surface. In this way, to adapt to temperature limits in maize creation, a thorough arrangement of changes in social just as in atomic procedures, (for example, rearing environment tough genotypes) and a worked-on comprehension of the hereditary, physiological, and sub-atomic reactions to temperature limits are required. Harvest plants normally experience distinctive biotic and abiotic focuses at the same time that cause numerous morphological and physiological irritations, bringing about hindered plant development and diminished grain yields (Cho et al., 2010; Chen et al., 2012) (Figure 4). 
Gillani SFA et al. (2021). Not Bot Horti Agrobo 49(4):12525

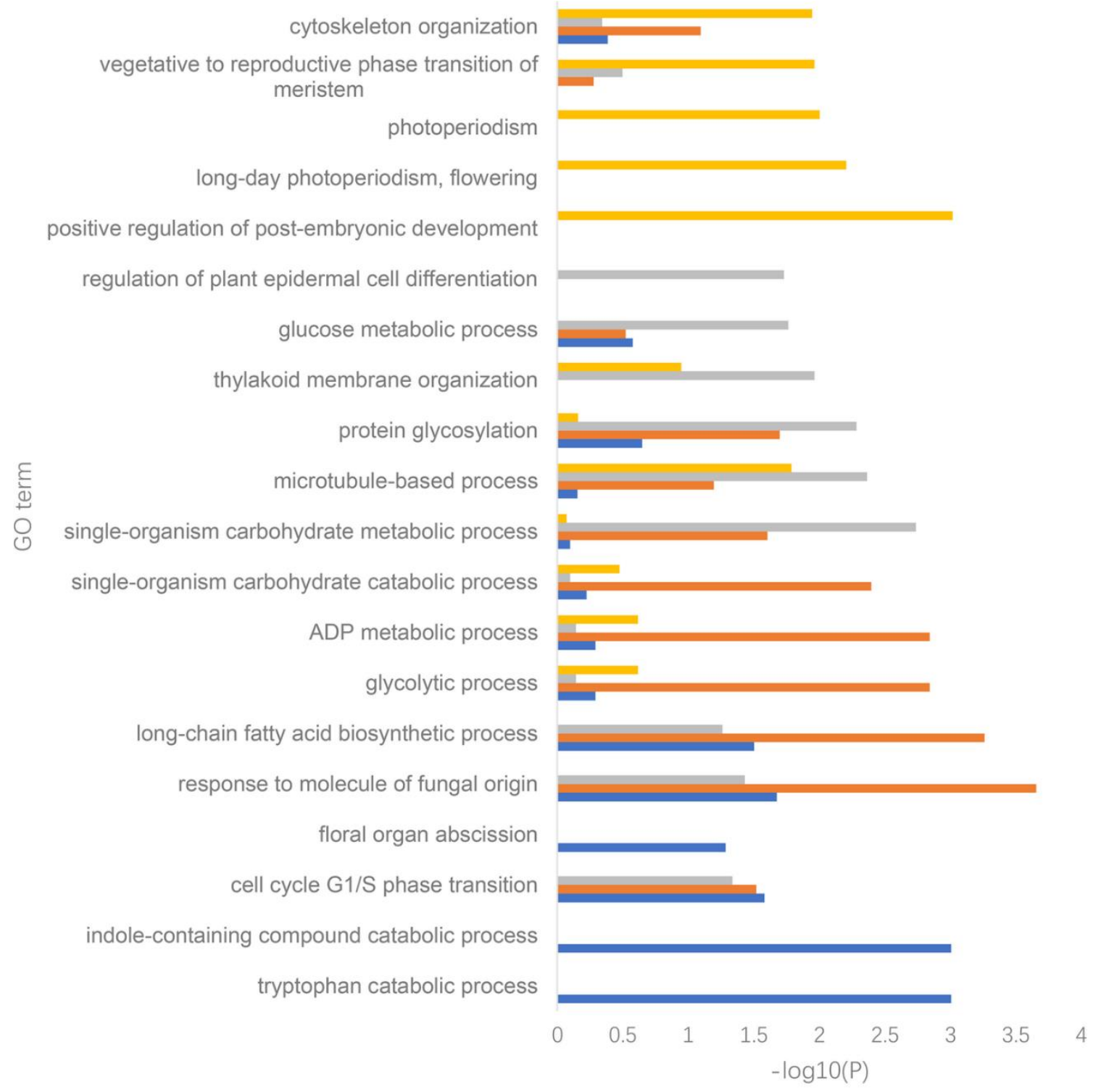

$m \mathrm{SI}=\mathrm{LP}=\mathrm{BW} \equiv \mathrm{BN}$

Figure 4. An overview of different processes initiated in maize during cold stress

Moreover, the maize plant just executes sped up endosperm advancement under raised day-and evening time temperature, not just under day-time warming (Tian et al., 2017), recommending that warmth stress sway changes extraordinarily with the hour of day and seriousness of stress. It clarifies the impact of warm weight on conceptive improvement in maize. Physio-metabolic: Inadequate photosynthates in cold-focused on plants are frequently considered as a significant restricting element for yield (Goddard et al., 2009). By the by, considering the C4 organic chemistry of maize crop, ordinarily, photosynthate supply isn't restricting (Tominaga et al., 2008). Subsequently, the essential driver of yield misfortune under raised temperatures for the maize crop during the grain filling period is the sped up formative cycle. 


\section{Transcription}

To further identify candidate resistance genes positioned around the GWAS-identified loci, the resistant rice variety, NSIC RC154, and the susceptible variety CT 9737-6-1-3P-M (both confirmed) were grown and inoculated with the more virulent $X o o$ race P6 in a greenhouse by the leaf-clipping method Hoggar et al., 2008). From each rice variety, leaves sample were obtained at 12, 24, 48, and $72 \mathrm{hpi}$, respectively, and each treatment has three replicates. Control samples of non-inoculated, fresh leaves of seedlings at $12 \mathrm{~h}$ were also collected. Place all leaf samples in liquid nitrogen and stored at $-80^{\circ} \mathrm{C}$ for their RNA isolation. Total RNA was isolated with the Plant Total RNA Isolation Kit (Sangon Biotech, Shanghai, China), according to the manufacturer's instructions. We used the NEBNext Ultra ${ }^{\text {rx }}$ RNA Library Prep Kit for Illumina (NEB, USA) for RNA-Seq libraries construction. The Illumina Hi-Seq platform was used sequencing, and 125-bp pairedend reads were generated. Among raw data, the reads having a low-quality score and those containing adaptor sequences and stretches of -Ns were removed. An index of the Nipponbare rice reference genome was built using Bowtie v2.2.3, to which the above paired-end reads were aligned using TopHat v2.0.12 (Hussain et al, 2006; Izaurralde et al., 2011; Hussain et al., 2019). To count the number of reads mapped to each gene, HTSeq v0.6.1 software was used (Kang et al., 2008). The expression value of each gene was present based on FPKM (fragments per kilobase of transcript sequence per million) that calculated using Cuffdiff software (v2.2.1).

The differential expression analysis of two treatments (each treatment contains three biological replicates) was carried out in R, using the "DESeq" package (v1.18.0) (Kawahara et al., 2016). Differential expression levels of gene in the two treatments sample comparisons were determined based on the negative binomial distribution. Benjamini and Hochberg's approach was used to adjust $P$-values for controlling the false discovery rate (FDR). Genes with the log twofold change $\mid>1$ and adjusted $P$-values of $<0.05$ were designated as differentially expressed (Koseki et al., 2010).

\section{GWAS may enlighten the debate over "missing heritability}

Grain yield diminishes when yield arrangement activities are led sooner than typical. Key protein exercises, for example, ADP-glucose pyrophosphorylase (engaged with starch biosynthesis) are additionally restricted at various levels, including both the transcriptional and post-transcriptional levels (Fujino et al., 2004). Strikingly, a high temperature at the grain filling stage lessens amyloplast biogenesis and endosperm cell division, causing abatement in the grain size (Edreira et al., 2011). Starch amasses in the creating grain through a perplexing organization of compounds (sucrose synthase, solvent starch synthase) directing this pathway (Gourdji et al., 2013). Warmth stress restricts these chemical exercises and weakens starch gathering during the grain filling and solidifying measure (Gu et al., 2013). High temperature $\left(>30^{\circ} \mathrm{C}\right)$ intrudes on the ordinary amyloplast replication cycle and cell division in grains, in this way contracting sink size (Hernández et al., 2005). Moreover, high temperature influences the physicochemical properties (starch, protein, and solvent sugar substance) of waxy maize during the grain filling measure, coming about in grains with unsatisfactory quality (Han et al., 2008).

Warmth stress additionally upsets the ordinary physiological cycles needed for ideal maize development and improvement. Diminished biomass absorption and grain fetus removal are the key physiological cycles bringing about decreased grain number in cold-focused on plants (Fang et al., 2017; Hartmann et al., 2000). Warmth stress up to $36^{\circ} \mathrm{C}$ essentially diminished the radiation use effectiveness (Hasanuzzaman et al., 2020), and less dynamic nitrogen and carbon digestion systems add to a decline in dry matter collection (Hayashi et al., 2016). The conversation above proposes that radiation use proficiency, biomass collection, and the sourcesink proportion are the urgent determinants of conclusive grain yield and the gather record under cold pressure conditions. Taken together, cold pressure contrarily impacts dusts reasonability and silks' receptivity, prompting a critical reduction in seed set and monetary yield. Maize is a chilly delicate plant, and frequently, yield is restricted in cool, sticky areas (e.g., Central Europe). 
In these areas, when maize crop is presented to cold pressure, the development rate will in general diminish while development span is delayed. In this manner, low temperature debilitates the seedling and may likewise stop the grain filling rashly toward the finish of the development cycle (Hoggart et al., 2008; Fujino et al., 2011; Hieke et al., 2014), bringing about lower and conflicting grain creation in uneven and mild regions. Injury to plant cells or tissue under chilling pressure during the early seedling stage or low temperatures at the conceptive stage in maize may shift contingent on the pressure term and its degree. Low temperature stress, described by plant openness to a temperature range under $10^{\circ} \mathrm{C}$ for an adequate span, can interfere with the ordinary interaction of yield development, beginning from the early seedling stage to the later conceptive stages (Wang et al., 2019).

Physio-metabolic: A temperature around $8-10^{\circ} \mathrm{C}$ postpones seedling development and causes a decrease in the root/shoot proportion and chlorophyll content during the early development cycle in maize (Hussain et al., 2019), while a temperature from 4 to $10^{\circ} \mathrm{C}$ may stifle chlorophyll combination and causes a serious decrease in photosystem II (PS II) movement (Hussain et al, 2019). Low temperature stress contrarily impacts chloroplast and thylakoid structures, chemical exercises, and the Calvin cycle by lessening metabolite transport (Yan et al., 2009). While examining cell divider properties under chilling pressure $\left(12-14^{\circ} \mathrm{C}\right)$, Cell divider gelatin content and gelatin methylesterase action become lower in a cool delicate maize half breed (Zhang et al., 2019). Different physiological and biochemical problems can be seen in photosynthetic apparatus, cell layers, and compound exercises under low temperature stress (Yang et al., 2019).

Chen et al. (2012) announced a critical ascent in malondialdehyde (MDA) substance and cell layer porousness because of chilling injury at the early seedling stage, with diminished substance of water, proline, and chlorophyll in maize leaves (Huang et al., 2017). Low temperature stress additionally makes shoots and roots large scale supplement $(\mathrm{N}, \mathrm{P}, \mathrm{K}, \mathrm{Ca}, \mathrm{Mg}$ ) inadequate by restricting metabolite transport (Kawahara et al,, 2016). In any case, when maize plants are presented to chilling temperatures of $7-10^{\circ} \mathrm{C}$, they produce flagging mixtures (e.g., nitric oxide and abscisic corrosive) in safeguard (Koseki et al., 2010). Low temperature stress makes harm macromolecules, cell designs, and layers because of the over-the-top creation of responsive oxygen species (ROS) (Cho et al., 2010; Fujino et al., 2011; Kovach et al., 2007). In safeguard, plants produce more cell reinforcement chemicals including superoxide dismutase (SOD), peroxidase (POD), and proline (Yu et al., 2006; Segura et al., 2012).

Low temperature stress at grain filling can adjust the starch synthesis in grains by lessening the amylose content, eventually diminishing water dissolvability and starch growing force and expanding gelatinization temperatures (Han et al., 2008). Temperatures under $15^{\circ} \mathrm{C}$ during the late conceptive stage decrease the exercises of the photosynthetic mechanical assembly just as paces of sucrose phosphate synthase, phosphoenol pyruvate carboxylase, and sucrose synthase. It will in general destabilize the absorption interaction, bringing about debilitated grain quality with unacceptable quality parts and poor actual grain surface (Lei et al., 2014; Fahad et al., 2017; Fahad et al., 2021a; Fahad et al, 2021b; Fahad et al., 2021c; Fahad et al., 2021e). Aggregately, low temperature stress lessens the germination rate, development rate, and the photosynthetic rate, bringing about helpless yield. A schematic portrayal of the different impacts and components of warmth and cold stress. To adapt to the malicious impacts of temperature limits, it is unavoidable to receive different agronomic and reproducing options alongside cutting edge genomic apparatuses. Here, we talk about different techniques to battle temperature limits in maize trimming frameworks.

Environment keen agronomic practices for a particular trimming framework incorporate practices that assist ranchers with adjusting environment stresses or potentially decline efficiency misfortune. These practices are turning out to be progressively essential to alleviate the unfriendly impacts of temperature limits (Li et al., 2015; Lesk et al., 2016; Sajid et al., 2020; Mohammad et al,, 2020; Mohammad et al., 2020a). Change in planting time may help plants get away from the temperature outrageous stage at basic development stages ( $\mathrm{Li}$ et al., 2019). In the North China Plain, maize crops have been faced with scenes of chilling and warmth stresses lately. Adjustment in planting time decreased the yield misfortunes altogether by limiting the danger of warmth 
and chilling harm during the silking and grain filling stages, individually (Foyer et al., 2002; Senol et al., 2020; Amjad et al., 2020).

\section{Variation above the genomic level can function in a complementary manner}

While changing to longer seasons, cultivars likewise improved the grain yield (going from 13\% to 38\%) by effectively alleviating the grave impacts of expanded warming patterns of thirty years ( $\mathrm{Li}$ et al., 2019). In semi-bone-dry regions (e.g., Sub-Saharan African nations), odds of maize crop disappointment are exceptionally high due to the unforgiving environment. There, the innovation of dry soil planting (DSP) is extremely viable to accomplish sufficient grain yield (Li et al., 2014). Ranchers plant seeds not long before the stormy season in dry soil. Since seeds will be in soil at the hour of downpour, they can begin the germination cycle in a flash subsequent to getting dampness. Such innovations can be reinforced with man-made reasoning all the more precisely foreseeing the stormy season (Li et al., 2014). Appropriation of cultivars with more warm time prerequisites can likewise essentially expand the yield by the deferral in development and broadened conceptive development span ( $\mathrm{Li}$, et al., 2011). Along these lines, ranchers need to adjust to the future environment by streamlining the planting date, maize earliness, and dry soil planting and choosing cultivars with more warm time necessities as indicated by their neighborhood pedoclimatic conditions.

\section{Reproducing for cold tolerance}

Distinguishing proof of reasonable guardians is fundamental for any reproducing program, remembering the destinations of the investigation. For example, the determination of high-yielding warmth lenient assortments to be utilized as guardians is a pre-essential to begin a reproducing program focused on the improvement of high-temperature-open minded maize cultivars. Here, we enroll a few maize genotypes including ingrained lines and half and halves that showed critical warmth resistance and, in this manner, can fill in as significant reproducing materials to introgress cold resilience in world class maize cultivars. Also, the recognizable proof of key determination lists is urgent for the choice of lenient cultivars or wild species. Leaf terminating, tuft impact, decoration sterility (TS), anthesis-silking stretch (ASI), and senescence are contrarily related, while dust shedding length (PSD), seed setting rate (SSP), and chlorophyll content are decidedly associated lists with grain yield in maize under cold pressure (Farooq et al., 2009). As of late, it was tracked down that high temperature influences the carbon dioxide swapping scale (CER) in maize, which contrarily influences crop development rate, grain number, and last grain yield (Fang et al., 2020; Muhammad et al., 2020).

Photosynthesis wellness is basic in choosing the exhibition of maize crops under cold pressure conditions (Atwell et al., 2010). Supporting a good pace of photosynthesis action under cold pressure is fundamental to diminish efficiency misfortune (Piepho et al., 2007; Pertea et al., 2016). A few pointers of photosynthesis wellness have been accounted for, for example, chlorophyll substance, carotenoids, and stay-green plant engineering which are decidedly associated with the pace of photosynthesis (Portolés et al., 2007). Standardized contrast vegetative record (NDVI), in view of the trademark reflectance highlights of maize covering, is a proficient marker of the stay-green quality (Pugh et al, 2010; Fazli et al., 2020; Md et al., 2020). In this way, utilizing these qualities in rearing projects of warmth lenient high-yielding maize cultivars can increment regenerative achievement, photosynthesis proficiency (NDVI), and other yield-related attributes under cold pressure.

Wild family members and far off guardians in intra-explicit crosses are extremely valuable assets to introgress novel qualities for maize improvement. Teosinte, an ancestor of developed maize, harbors a ton of commendable qualities to endure a blend of various anxieties. Teosinte is very much adjusted to the high temperature climate as it shows somewhat lower harm and supports chlorophyll content under cold pressure $\left(36\right.$ to $45^{\circ} \mathrm{C}$ ) and portrays higher endurance limit even at $55^{\circ} \mathrm{C}$ (Qin et al., 2008: Gopakumar et al., 2020). In this way, it can fill in as an expected hotspot for maize improvement programs. In any case, it was inadequately misused for the distinguishing proof and introgression of such qualities. Before, an exertion was made to 
recognize a warmth open minded assortment of teosinte called "Florida" and effectively introgressed cold resilience from teosinte to developed corn (Rafique et al., 2019; Md et al., 2020).

As per another report, between sub specific mixtures of teosinte $\times$ maize was created, which showed expanded thermo-capacity to bear a few developments and yield-related characteristics (Qin et al., 2008). In this way, the misuse of wild family members and far off guardians in intra-explicit crosses could demonstrate an extremely valuable asset to introgress novel qualities for maize improvement. The potential systems engaged with yield misfortune aversion by cold-open minded maize. The maize crop is very delicate to low temperatures and requires genuinely high temperatures for ideal development and creation. To stay away from incessant scenes of warmth and dry season during the conceptive stage, ranchers develop this harvest early (Commuri et al., 2001; Raza et al., 2019; Farah et al., 2020; Sadam et al., 2020). Notwithstanding, early developed maize is regularly presented to chilling pressure, which may prompt low harvest execution because of helpless germination or absence of seedling endurance (Read et al., 2001; Unsar Naeem et al., 2020).

Table 3. Summary of the characteristics of three multi-parent population designs in maize

\begin{tabular}{|l|c|c|c|}
\hline \multicolumn{1}{|c|}{ Character } & Population A & Population B & Population C \\
\hline Cross pattern & Interconnect & Interconnect & Disconnect \\
\hline Genetic diversity & High & High & High \\
\hline Founder contribution & Extremely imbalanced & Balanced & Approximate balanced \\
\hline Population size & Large & Intermediate & Large/very large \\
\hline Algorithm complexity & Low & High & Intermediate \\
\hline Recombinant events & Intermediate & High & Intermediate \\
\hline Developmental cost & High & Very high & Low \\
\hline Collaborative research & Possible & No & Suitable \\
\hline
\end{tabular}

Sweet corn is considerably more delicate to low temperatures contrasted and field maize. Achieve high development rates and lively seedlings under low temperatures to adjust maize for early planting (Reeves et al., 2001). Enormous variety is available in maize germplasm for variation to cold resilience, particularly in intriguing maize populaces (Riva-Roveda et al., 2016). Maize cultivars of mild districts (e.g., Europe) have been broadly utilized in chilling resistance reproducing programs dependent on great harvest execution (Hussain et al., 2019). Here, we present a few cold-open minded maize cultivars created all throughout the planet that could be used in rearing projects. Mid-parent execution is a helpless pointer of mixture choice for cold resistance, and testcross execution ought to be utilized as a solid marker for quantitative quality locus (QTL) planning to foster stable markers (Robinson et al, 2010). Recognizable proof of dependable choice records for cold resistance is critical to screen germplasm for the reproducing programs (Cho et al., 2010). A few attributes like photosynthetic rate, stomatal conductance, quantum proficiency, dry matter creation, leaf weight and region, and water use productivity are acceptable choice records to acknowledge cold resistance in maize (Hoggart et al., 2008).

Hence, the recognizable proofs of cold-open minded germplasm dependent on solid determination lists can proficiently further develop execution. Hereditarily adjusted yields (GMCs) could fill in as a helpful asset for novel characteristics (Saito et al., 2004; Saito et al., 2010). In ongoing many years, fast advancement in plant sub-atomic science has sped up the pace of harvest improvement. A few methodologies including quantitative attribute locus (QTL) planning, transcriptomics, marker-helped determination (MAS), map-based quality cloning, and genome altering, (for example, grouped consistently interspaced short palindromic rehash ((CRISPR)/CRISPR-related 9, Cas9) have been used for choice and improvement of plant characteristics in a few yields. 


\section{Marker-assisted selection (MAS)}

Molecular techniques are helpful to improve any specific trait of plant (Rasheed et al., 2021c). Pyramiding helpful qualities followed by the determination of advantageous plant material has been quite difficult for plant raisers. It is almost difficult to pyramid different alluring qualities through traditional reproducing because of linkage. Marker-helped choice (MAS) fundamentally worked on the productivity just as diminished the time required for complex characteristic determination like dry spell, salt, cold, and warmth resilience (Sánchez et al, 2014). Different qualities control cold resistance attributes in maize crops. After the disclosure of various atomic markers for cold and warmth resistance in maize, it is currently conceivable to screen the open-minded germplasm at the early development stage, saving time, work, and space (Hayashi et al., 2016; Sandhu et al., 2018; Ayman et al., 2020). Single nucleotide polymorphisms (SNPs) are ordinarily utilized atomic markers because of their plenitude in the genome, simple location examination, and copredominance nature (Atwell et al., 2010). A few SNPs related with qualities administering warmth and cold resilience were recognized, which could be utilized in MAS to speed up the determination interaction and accelerate generally reproducing programs (Fujino et al., 2010; Zia-ur-Rehman et al., 2020).

\section{Future perspective}

Roots and shoots evolved together for nearly 3.5 million years. However, owing to directional selection for yield in the past century, root attributes were completely neglected in breeding programs, unless the improvement was indirect. Therefore, a future breeding dimension should focus simultaneously on the recruitment of lost root system variations for yield and sustainability. Several studies reported that root system attributes enhance shoot architecture for yield and drought fitness in cereals, reflecting that root should be the foremost breeding target of the future.

The natural genetic diversity in differential root system architecture may be useful to understand drought adaptation mechanisms and improve cultivars by generating beneficial root architecture. To date, studies have reported and validated QTLs associated with root system traits, such as root length, biomass, number, angle, volume, diameter, density, and xylem vessel size, under drought stress conditions. More importantly, the diversity of the wild relatives of crops showed remarkable root system variations that have great potential in drought stress adaptation. Here, we summarized a considerable amount of donor genotypes, including wild relatives (Supplementary Table S1), but very limited strategies have been undertaken to exploit these lines in resilient breeding programs. These promising donor parents need to be introgressed into elite backgrounds to enhance the stress-adaptive potential of the cultivated gene pool.

The enhancement of root-related drought stress adaptation by applying classical breeding is difficult owing to the complexity levels of these traits. Genomic and phenomic approaches are gaining popularly as important tools that allow in-depth analyses of crops to increase our understanding of the complexity of the mechanisms underlying stress adaptation. Although both cis- and trans-genetic components, along with epigenetics, are involved directly in trait complexity, the role of cis-genetic modules appears to be more influential on the quantitative divergence in expression of genes controlling polygenic traits across dynamic environments. Therefore, interactions form the biggest challenge in the precise genetic determination of these traits under field conditions. This scenario demands an expression QTL analysis as a high-resolution genomics approach for the precise dissection of traits at morphological and physiological levels across varying environments. In addition, over the last decades, NGS and bioinformatics tools have been rapidly advancing, allowing the discovery of new genes and regulatory sequences controlling diverse complex traits. 


\section{Conclusions}

All things considered, high-throughput phenotyping and genotyping offices are not broad among maize raisers of helpless nations because of confined assets, noticeable by the sluggish pace of harvest improvement around there. This causes a gigantic contrast in the normal yield of maize among created and immature nations. For instance, the normal maize yield in the United States is 13.2 tons/ha, which is $340 \%$ more than the normal grain yield of 3 tons/ha in South Africa and 0.9 tons/ha in Mozambique. Another key restriction is deficient information on the atomic systems of complex attributes like warmth and cold resistance. Absence of proper foundation, insufficient functional help, restricted HR, and absence of empowering strategies and legal and administrative systems are the key factors that hamper the prosperous development of sub-atomic reproducing in agricultural nations.

A genuine exertion is important to address these critical difficulties among maize raisers across the world to guarantee feasible maize creation and food security. This could be accomplished through subsidized preparing of maize raisers from agricultural nations at worldwide exploration stations like CIMMYT, ICARDA, and so forth, to foster a fantastic human asset for mid-economy nations. Another key advance could be to give instruments to high-throughput phenotyping and genotyping just as seeds of further developed cultivars to these raisers, which can support their yield potential. Warm anxieties at basic development phases of maize diminish the grain yield, dietary benefit, and overall gain of ranchers. Hereditary variety exists among various cultivars for cold and warmth resilience, which shows the requirement for more precise plant reproducing projects to have site-explicit plant assets to further develop maize crop execution under restricting developing conditions. Exogenous utilization of manufactured and regular plant development controllers at low focuses additionally lessens usefulness misfortune under such conditions. New reproducing procedures, for example, marker-helped rearing and genome altering, especially the sans transgene CRISPR-Cas9 framework, offer incredible potential for the advancement of environment versatile cultivars in a nearly more limited time. Moreover, a solid foundation for assessment of maize germplasm dependent on high-throughput phenotyping in addition to genotyping is needed in agricultural nations.

\section{Authors' Contributions}

This research was supported by Gansu Provincial Key Laboratory of Aridland Crop Science, Gansu Agricultural University (No. GHSJ-2020-Z5), the Fuxi Talent Project of Gansu Agricultural University, China (No. GAUFX-02Y09), Lanzhou Science and Technology Bureau (No.2020-RC-122). All authors read and approved the final manuscript.

\section{Acknowledgements}

This work was supported by the central government guides the special project of local science and technology development. The Fuxi Talent Project of Gansu Agricultural University, China (No. GAUFX02Y09).

\section{Conflict of Interests}

The authors declare that there are no conflicts of interest related to this article. 


\section{References}

Abdul S, Muhammad AA, Shabir H, Hesham A El E, Sajjad H, Niaz A, ... Rahul D (2021). Zinc nutrition and arbuscular mycorrhizal symbiosis effects on maize (Zea mays L.) growth and productivity. Saudi Journal of Biological Sciences 28(11):6339-6351. https://doi.org/10.1016/j.sjbs.2021.06.096

Alam MA, Seetharam K, Zaidi PH Dinesh A, Vinayan MT, Nath UK (2017). Dissecting cold stress tolerance in tropical maize (Zea mays L.). Field Crops Research 204:110-119. https://doi.org/10.1016/j.fcr.2017.01.006

Alexander DH, Novembre J, and Lange K (2009). Fast model-based estimation of ancestry in unrelated individuals. Genome Research 19:1655-1664. https://doi.org/10.1101/gr.094052.109

Amjad SF, Mansoora N, Din IU, Khalid IR, Jatoi GH, Murtaza G, ... Datta R (2021). Application of zinc fertilizer and mycorrhizal inoculation on physio- biochemical parameters of wheat grown underwater-stressed environment. Sustainability 13:11007. https://doi.org/10.3390/su131911007

An Y, Dai X, and Zhang WH (2012). An r2r3-type myb gene, osmyb2, is involved in salt, cold, and dehydration tolerance in rice. Journal of Experimental Botany 63:2541-2556. https://doi.org/10.1093/jxb/err431

Anders S, Pyl PT, Huber W (2015). HTSeq-a Python framework to work with high-throughput sequencing data. Bioinformatics 31(2):166-169. https://doi.org/10.1093/bioinformatics/btu638

Apel K, Hirt H (2004). Reactive oxygen species: Metabolism, oxidative stress, and signal transduction. Annual Review Plant Biology 55:373-399. https://doi.org/10.1146/annurev.arplant.55.031903.141701

Applequist WL, Cronn R, Wendel JF (2001). Comparative development of fiber in wild and cultivated cotton. Evolution and Development 3(1):3-17. https://doi.org/10.1046/j.1525-142x.2001.00079.x

Ardy OJ, H and Ekemans XV (2002). SPAGeDi a versatile computer program to analyses spatial genetic structure at the individual or population levels. Molecular Ecology Resources 2:618-620. https://doi.org/10.1046/j.14718286.2002.00305.X

Ashfaq AR, Uzma Y, Niaz A, Muhammad AA, Fahad S, Haider S, ... Rahul D (2021). Toxicity of cadmium and nickel in the context of applied activated carbon biochar for improvement in soil fertility. Saudi Society of Agricultural Sciences https://doi.org/10.1016/j.sjbs.2021.09.035

Atwell S, Huang YS, Vilhjalmsson BJ, Willems G, Horton M, Li Y, ... Nordborg M (2010). Genome-wide association study of 107 phenotypes in Arabidopsis thaliana inbred lines. Nature 465:627-631. https://doi.org/10.1038/nature08800

Ayers KL, Cordell HJ (2010). SNP selection in genome-wide and candidate gene studies via penalized logistic regression. Genetic Epidemiology 34:879-891. https://doi.org/10.1002/gepi.20543

Bajželj B, Richards KS, Allwood JM, Smith P, Dennis JS, Curmi E, Gilligan CA (2014). Importance of food-demand management for climate mitigation. Nature Climate Change 4:924-929. https://doi.org/10.1038/nclimate2353

Bano S, Aslam M, Saleem M, Basra S, Aziz K (2015). Evaluation of maize accessions under low temperature stress at early growth stages. Journal of Animal and Plant Science 25:392-400.

Barnabás B, Jäger K, Fehér A (2008). The effect of drought and cold stress on reproductive processes in cereals. Plant Cell and Environment 31:11-38. https://doi.org/10.1111/j.1365-3040.2007.01727.x

Bates D, Machler M, Bolker BM, Walker SC (2015). Fitting linear mixed-effects models using lme4. Journal of Statistical Software 67(1):1-48. https://doi.org/10.18637/jss.v067.i01

Bilska-Kos A, Solecka D, Dziewulska A, Ochodzki P, Jończyk M, Bilski H, Sowiński P (2017). Low temperature caused modifications in the arrangement of cell wall pectins due to changes of osmotic potential of cells of maize leaves (Zea mays L.). Protoplasma 254:713-724. Https://doi.org/10.1007/s00709-016-0982-y

Boehlein SK, Liu P, Webster A, Ribeiro C, Suzuki M, Wu S, ... Settles AM (2019). Effects of long-term exposure to elevated temperature on Zea mays endosperm development during grain fill. Plant Journal 99:23-40. https://doi.org/10.1111/tpj.14283

Cai C, Guozhong Z, Tianzhen Z, Wangzhen G (2017). High-density $80 \mathrm{~K} \mathrm{SNP}$ array is a powerful tool for genotyping $G$. hirsutum accessions and genome analysis. BMC Genomics 18(1):654. https://doi.org/10.1186/s12864-0174062-2

Cárcova J, Otegui ME (2001). Ear temperature and pollination timing effects on maize kernel set. Crop Physiology and Metabolism 41:1809-1815. https://doi.org/10.2135/cropsci2001.1809 
Change IC, Manning M, Chen Z, Marquis M, Averyt KB, Tignor M., Miller HL (2007). Contribution of Working Group I to the Fourth Assessment Report of the Intergovernmental Panel on Climate Change. Cambridge University Press. The Physical Science Basis. Cambridge, UK; New York, NY, USA, Volume 996.

Chen J, Xu W, Velten J, Xin Z, Stout J (2012). Characterization of maize inbred lines for drought and cold tolerance. Journal of Soil Water Conservation 67:354-364. https://doi.org/10.2489/jswc.67.5.354

Chen Y, Guo Z, Dong L, Fu Z, Zheng Q, Zhang G, ... Saud S (2021). Turf performance and physiological responses of native Poa species to summer stress in Northeast China. PeerJ 9:e12252. http://doi.org/10.7717/peerj.12252

Chen ZJ, Scheffler BE, Dennis E, Triplett BA, Zhang T, Guo W, ... Paterson AH (2007). Toward sequencing cotton (Gossypium) genomes. Plant Physiology 145(4):1303-1310. https://doi.org/10.1104/pp.107.107672

Cho S (2010). Joint identification of multiple genetic variants via Elastic-Net variable selection in a genome-wide association analysis. Annals of Human Genetics 74:416-428. https://doi.org/10.1111/j.14691809.2010.00597.x

Cicchino M, Edreira J, Uribelarrea M, Otegui M (2010). Heat stress in field-grown maize: Response of physiological determinants of grain yield. Crop Science 50:1438-1448. https://doi.org/10.2135/cropsci2009.10.0574

Commuri P Jones RJ (2001). High temperatures during endosperm cell division in maize. Crop Science 41:1122-1130. https://doi.org/10.2135/cropsci2001.4141122x

Deeks MJ, Calcutt JR, Ingle EKS, Hawkins TJ, Chapman S, Richardson AC, ... Smertenko AP (2012). A superfamily of actin-binding proteins at the actin-membrane nexus of higher plants. Current Biology 22(17):1595-1600. https://doi.org/10.1016/j.cub.2012.06.041

Dubouzet JG, Sakuma Y, Ito Y, Kasuga M, Dubouzet EG, Miura S (2003). OsDREB genes in rice, (Oryza sativa L.) encode transcription activators that function in drought high salt and cold responsive gene expression. Plant Journal 33:751-763. https://doi.org/10.1046/j.1365-313X.2003.01661.x

Edreira JR, Carpici EB, Sammarro D, Otegui M (2011). Heat stress effects around flowering on kernel set of temperate and tropical maize hybrids. Field Crops Research 123:62-73. https://doi.org/10.1016/j.fcr.2011.04.015

Emre B, Ömer SU, Martín LB, Andre D, Fahad S, Rahul D, ... Subhan D (2021) Studying soil erosion by evaluating changes in physico-chemical properties of soils under different land-use types. Journal of the Saudi Society of Agricultural Sciences 20:190-197. https://doi.org/10.1016/j.jssas.2021.01.005

Esim N, Atici Ö (2016). Relationships between some endogenous signal compounds and the antioxidant system in response to chilling stress in maize (Zea mays L.) seedlings. Turkish Journal of Botany 40:37-44.

Fahad S, Bajwa AA, Nazir U, Anjum SA, Farooq A, Zohaib A, ... Huang J (2017) Crop production under drought and heat stress: Plant responses and management options. Frontiers in Plant Science 8:1147. https://doi.org/10.3389/fpls.2017.01147

Fahad S, Sönmez O, Saud S, Wang D, Wu C, Adnan M, Arif M, Amanullah (2021e). Engineering tolerance in crop plants against abiotic stress. First edition. Footprints of climate variability on plant diversity. CRC Press, Boca Raton.

Fahad S, Sonmez O, Saud S, Wang D, Wu C, Adnan M, Turan V (2021c). Developing climate resilient crops: improving global food security and safety. First edition. Footprints of climate variability on plant diversity. CRC Press, Boca Raton.

Fahad S, Sönmez O, Saud S, Wang D, Wu C, Adnan M, Turan, V (2021a). Plant growth regulators for climate-smart agriculture. First edition. Footprints of climate variability on plant diversity. CRC Press, Boca Raton, FL.

Fahad S, Sonmez O, Saud S, Wang D, Wu C, Adnan M, Turan, V (2021b). Climate change and plants: biodiversity, growth and interactions. First edition. Footprints of climate variability on plant diversity. CRC Press, Boca Raton.

Fahad S, Sönmez O, Turan V, Adnan M, Saud S, Wu C, Wang D (2021d). Sustainable soil and land management and climate change. First edition. Footprints of climate variability on plant diversity. CRC Press, Boca Raton.

Fang DD, Naoumkina M, Thyssen GN, Bechere E, Li P, Florane CB (2020). An EMS-induced mutation in a tetra tricopeptide repeat-like superfamily protein gene (Ghir_A12G008870) on chromosome A12 is responsible for the li(y) short fiber phenotype in cotton. Theoretical and Applied Genetics 133(1):271-282. https://doi.org/10.1007/s00122-019-03456-4

Fang H, Meng Q, Xu J, Tang H, Tang S, Zhang H (2015). Knock-down of stress inducible ossrfp1 encoding an e3 ubiquitin ligase with transcriptional activation activity confers abiotic stress tolerance through enhancing antioxidant protection in rice. Plant Molecular Biology 87:441-458. https://doi.org/10.1007/s11103-0150294-1 
Fang L, Wang Q, HuY, Jia Y, Chen J, Liu B, Zhang Z, Guan X, Chen S, Zhou B (2017). Genomic analyses in cotton identify signatures of selection and loci associated with fiber quality and yield traits. Nature Genetics 49(7):1089-1098. https://doi.org/10.1038/ng.3887

Farah R, Muhammad R, Muhammad SA, Tahira Y, Muhammad AA, Maryam A, ... Fahad S (2020). Alternative and nonconventional soil and crop management strategies for increasing water use efficiency. In: Fahad $S$, Hasanuzzaman M, Alam M, Ullah H, Saeed M, Khan AK, Adnan M (Eds). Environment, Climate, Plant and Vegetation Growth. Springer Publ Ltd, Springer Nature Switzerland AG, pp 323338. https://doi.org/10.1007/978-3-030-49732-3

Farooq M, Aziz T, Basra S, Cheema M, Rehman H (2008). Chilling tolerance in hybrid maize induced by seed priming with salicylic acid. Journal of Agronomy Crop Science 194:161-168. https://doi.org/10.1111/j.1439037X.2008.00300.x

Farooq M, Aziz T, Wahid A, Lee DJ, Siddique KH (2009). Chilling tolerance in maize: Agronomic and physiological approaches. Crop Pasture Science 60:501-516.

Fazli W, Muhmmad S, Amjad A, Fahad S, Muhammad A, Muhammad N, ... Muhammad A (2020). Plant-microbes interactions and functions in changing climate. In: Fahad S, Hasanuzzaman M, Alam M, Ullah H, Saeed M, Khan AK, Adnan M (Eds). Environment, Climate, Plant and Vegetation Growth. Springer Publ Ltd, Springer Nature Switzerland AG, pp 397-420. https://doi.org/10.1007/978-3-030-49732-3

Foyer CH, Vanacker H, Gomez LD, Harbinson J (2002). Regulation of photosynthesis and antioxidant metabolism in maize leaves at optimal and chilling temperatures. Plant Physiology and Biochemistry 40:659-668. https://doi.org/10.1016/S0981-9428(02)01425-0

Fujino K, Matsuda Y (2010). Genome-wide analysis of genes targeted by qLTG3-1 controlling low-temperature germinability in rice. Plant Molecular Biology 72:137-152. https://doi.org/10.1007/s11103-009-9559-X

Fujino K, Sekiguchi H (2011). Origins of functional nucleotide polymorphisms in a major quantitative trait locus, qLTG3-1, controlling low-temperature germinability in rice. Plant Molecular Biology 75:1-10. https://doi.org/10.1007/s11103-010-9697-1

Fujino K, Sekiguchi H, Sato T, Kiuchi H, Nonoue Y, Takeuchi Y (2004). Mapping of quantitative trait loci controlling low-temperature germinability in rice (Oryza sativa L.). Theoretical and Applied Genetics 108:794-799. https://doi.org/10.1007/s00122-003-1509-4

Goddard ME, Wray NR, Verbyla K, Visscher PM (2009). Estimating effects and making predictions from genome-wide marker data. Statistical Science 24:517-529. https://doi.org/10.1214/09-STS306

Golub GH, van Loan CF (2016). Matrix computations. ( $3^{\text {rd }}$ Ed). Baltimore and London. The Johns Hopkins University Press.

Gopakumar L, Bernard NO, Donato V (2020). Soil microarthropods and nutrient cycling. In: Fahad S, Hasanuzzaman M, Alam M, Ullah H, Saeed M, Khan AK, Adnan M (Eds). Environment, Climate, Plant and Vegetation Growth. Springer Publ Ltd, Springer Nature Switzerland AG, pp 453-472. https://doi.org/10.1007/978-3-03049732-3

Gourdji SM, Sibley AM, Lobell DB (2013). Global crop exposure to critical high temperatures in the reproductive period: Historical trends and future projections. Environmental Research Letters 8:024041.

Gu X, Wang Y, He Y (2013). Photoperiodic regulation of flowering time through periodic histone deacetylation of the florigen gene FT. PLoS Biology 11(9):e1001649. https://doi.org/10.1371/journal.pbio.1001649

Habib ur R, Ashfaq A, Aftab W, Manzoor H, Fahd R, Wajid I, ... Wajid N (2017). Application of CSM-CROPGROCotton model for cultivars and optimum planting dates: Evaluation in changing semi-arid climate. Field Crops Research 238:139-152. http://dx.doi.org/10.1016/j.fcr.2017.07.007

Hafiz MH, Abdul K, Farhat A, Wajid F, Fahad S, Muhammad A, ... Hafiz FB (2020b). Comparative effects of organic and inorganic fertilizers on soil organic carbon and wheat productivity under arid region. Communications in Soil Science and Plant Analysis 51:1406-1422. https://doi.org/10.1080/00103624.2020.1763385

Hafiz MH, Wajid F, Farhat A, Fahad S, Shafqat S, Wajid N, Hafiz FB (2016). Maize plant nitrogen uptake dynamics at limited irrigation water and nitrogen. Environment Science and Pollution Research 24(3):25492557. https://doi.org/10.1007/s11356-016-8031-0

Hafiz MH, Farhat A, Shafqat S, Fahad S, Artemi C, Wajid F, Chaves CB, Wajid N, Muhammad M, Hafiz FB (2018). Offsetting land degradation through nitrogen and water management during maize cultivation under arid conditions. Land Degradation and Development 29:1366-1375. https://doi.org/10.1002/ldr.2933 
Hafiz MH, Muhammad A, Farhat A, Hafiz FB,Saeed AQ, Muhammad M, Fahad S, Muhammad A (2019). Environmental factors affecting the frequency of road traffic accidents: a case study of sub-urban area of Pakistan. Environmental Science and Pollution Research 26:11674-11685. https://doi.org/10.1007/s11356-019-047528

Han P, García-Ponce B, Fonseca-Salazar G, Alvarez-Buylla ER, Yu H (2008). AGAMOUS-LIKE 17, a novel flowering promoter, acts in a FT-independent photoperiod pathway. Plant Journal 55(2):253-265. https://doi.org/10.1111/j.1365-313X.2008.03499.x

Hartmann U (2000). Molecular cloning of SVP: A negative regulator of the floral transition in Arabidopsis. Plant Journal 21(4):351-360. https://doi.org/10.1046/j.1365-313x.2000.00682.x

Hasanuzzaman M, Bhuyan MH, MB Zulfiqar F, Raza A, Mohsin SM, Mahmud JA, ... Fotopoulos V (2020). Reactive oxygen species and antioxidant defense in plants under abiotic stress. Revisiting the crucial role of a universal defense regulator. Antioxidants 9:681. https://doi.org/10.3390/antiox9080681

Hayashi T (2016). Varietal difference in the effects of low temperature on tassel development in hybrid maize. Plant Production Science 19:230-237. https://doi.org/10.1080/1343943X.2015.1133236

Hayashi T, Makino T, Sato N, Deguchi K (2015). Barrenness and changes in tassel development and flowering habit of hybrid maize associated with low air temperatures. Plant Production Science 18:93-98. https://doi.org/10.1626/pps.18.93

Hepworth S, Valverde F, Ravenscroft D, Mouradov A, Coupland G (2002). Antagonistic regulation of flowering-time gene SOC1 by CONSTANS and FLC via separate promoter motifs. EMBO Journal 21:4327-4337. https://doi.org/10.1093/emboj/cdf432

Hernández ML, Mancha M, Martínez-Rivas JM (2005). Molecular cloning and characterization of genes encoding two microsomal oleate desaturases (FAD2) from olive. Phytochemistry 66(12):1417-1426. https://doi.org/10.1016/j.phytochem.2005.04.004

Hesham FA, Fahad S (2020) Melatonin application enhances biochar efficiency for drought tolerance in maize varieties: Modifications in physio-biochemical machinery. Agronomy Journal 112(4):1-22. https://doi.org/10.1002/agj2.20263

Hieke S, Binder H, Nieters A, Schumacher M (2014). minPtest - a resampling based gene region-level testing procedure for genetic case-control studies. Computational Statistics 29(1-2):51-63. https://doi.org/10.1007/s00180-012$0391-4$

Hoggart CJ, Whittaker JC, De Iorio M, Balding DJ (2008). Simultaneous analysis of all SNPs in genome-wide and resequencing association studies. PLoS Genetics 4(7):e1000130. https://doi.org/10.1371/journal.pgen.1000130

Hu Y, Chen JD, Fang L, Zhang ZY, Ma W, Niu YC, ... Lian JM (2019). Gossypium barbadense and Gossypium hirsutum genomes provide insights into the origin and evolution of allotetraploid cotton. Nature Genetics 51(4):739-748. https://doi.org/10.1038/s41588-019-0371-5

Huang C, Nie X, Shen C, You C, Li W, Zhao W, Zhang X, Lin Z (2017). Population structure and genetic basis of the agronomic traits of upland cotton in China revealed by a genome-wide association study using high-density SNPs. Plant Biotechnology Journal 15(11):1374-1386. https://doi.org/10.1111/pbi.12722

Huang X, Kurata N, Wei X, Wang Z X, Wang A, Zhao Q (2012). A map of rice genome variation reveals the origin of cultivated rice. Nature 490:497-501. https://doi.org/10.1038/nature11532

Huang XH, Feng Q, Qian Q, Zhao QA, Wang L, Wang AN (2009). High-throughput genotyping by whole-genome resequencing. Genome Research 19:1068-1076. https://doi.org/10.1101/gr.089516.108

Hund A, Richner W, Soldati A, Fracheboud Y,Stamp P (2007). Root morphology and photosynthetic performance of maize inbred lines at low temperature. European Journal of Agronomy 27:52-61. https://doi.org/10.1016/j.eja.2007.01.003

Hunter MC, Smith RG, Schipanski ME, Atwood LW, Mortensen DA (2017). Agriculture in 2050: Recalibrating targets for sustainable intensification. Bioscience 67:386-391. https://doi.org/10.1093/biosci/bix010

Hussain HA, Hussain S, Khaliq A, Ashraf U, Anjum SA, Men S, Wang L (2018). Chilling and drought stresses in crop plants: Implications, cross talk, and potential management opportunities. Frontiers in Plant Science 9:393. https://doi.org/10.3389/fpls.2018.00393

Hussain HA, Men S, Hussain S, Chen Y, Ali S, Zhang S, ... Liao C (2019). Interactive effects of drought and cold stresses on morpho-physiological attributes, yield, nutrient uptake and oxidative status in maize hybrids. Scientific Report 9:3890. https://doi.org/10.1038/s41598-019-40362-7 
Hussain HA, Shengnan M, Hussain S, Ashraf U, Zhang Q, Anjum SA, Ali I, Wang L (2019). Individual and concurrent effects of drought and chilling stresses on morpho-physiological characteristics and oxidative metabolism of maize cultivars. bioRxiv 829309. https://doi.org/10.1101/829309

Hussain MA, Fahad S, Rahat S, Muhammad FJ, Muhammad M, Qasid A, ... Juncai H (2020). Multifunctional role of brassinosteroid and its analogues in plants. Plant Growth Regulators. https://doi.org/10.1007/s10725-020$00647-8$

Hussain S, Khaliq A, Ali B, Hussain HA, Qadir T, Hussain S (2019). Temperature extremes: Impact on rice growth and development. In: Plant Abiotic Stress Tolerance. Springer: Cham, Switzerland, pp 153-171.

Hussain T, Khan IA Malik MA, Ali Z (2006). Breeding potential for high temperature tolerance in corn (Zea mays L.). Pakistan Journal of Botany 38:1185.

Ibrar K, Aneela R, Khola Z, Urooba N, Sana B, Rabia S, ... Salvatore M (2020). Microbes and environment: global warming reverting the frozen zombies. In: Fahad S, Hasanuzzaman M, Alam M, Ullah H, Saeed M, Khan AK, Adnan M (Eds). Environment, Climate, Plant and Vegetation Growth. Springer Publ Ltd, Springer Nature Switzerland AG, pp 607-634. https://doi.org/10.1007/978-3-030-49732-3

Ilyas M, Mohammad N, Nadeem K, Ali H, Aamir HK, Kashif H, Fahad S, Aziz K, Abid U (2020). Drought tolerance strategies in plants: a mechanistic approach. Journal of Plant Growth Regulation. https://doi.org/10.1007/s00344-020-10174-5

Iqra M, Amna B, Shakeel I, Fatima K,Sehrish L, Hamza A, Fahad S (2020). Carbon cycle in response to global warming. In: Fahad S, Hasanuzzaman M, Alam M, Ullah H,Saeed M, Khan AK, Adnan M (Eds). Environment, Climate, Plant and Vegetation Growth. Springer Publ Ltd, Springer Nature Switzerland AG. pp 116. https://doi.org/10.1007/978-3-030-49732-3

Izaurralde RC, Thomson AM, Morgan J, Fay P, Polley H, Hatfield JL (2011). Climate impacts on agriculture: Implications for forage and rangeland production. Agronomy Journal 103:371-381. https://doi.org/10.2134/agronj2010.0304

Jan M, Muhammad Anwar-ul-Haq, Adnan NS, Muhammad Y, Javaid I, Xiuling L, Depeng W, Fahad S, (2019). Modulation in growth, gas exchange, and antioxidant activities of salt-stressed rice (Oryza sativa L.) genotypes by zinc fertilization. Arabian Journal of Geoscience 12:775. https://doi.org/10.1007/s12517-019-4939-2

Kamarn M, Wenwen C, Irshad A, Xiangping M, Xudong Z, Wennan S, ... Tiening L (2017). Effect of paclobutrazol, a potential growth regulator on stalk mechanical strength, lignin accumulation and its relation with lodging resistance of maize. Plant Growth Regulators 84:317-332. https://doi.org/10.1007/s10725-017-0342-8

Kang HM (2008). Efficient control of population structure in model organism association mapping. Genetics 178:17091723. https://doi.org/10.1534/genetics.107.080101

Kawahara Y, Oono Y, Wakimoto H, Ogata J, Kanamori H, Sasaki H (2016). TENOR: database for comprehensive mRNA-Seq experiments in rice. Plant Cell Physiology 57:e7. https://doi.org/10.1093/pcp/pcv179

Koseki M, Kitazawa N, Yonebayashi S, Maehara Y, Wang Z.-X, Minobe Y (2010). Identification and fine mapping of a major quantitative trait locus originating from wild rice, controlling cold tolerance at the seedling stage. Molecular Genetics and Genomics 284:45-54. https://doi.org/10.1007/s00438-010-0548-1

Kovach M J, Sweeney MT, Mccouch SR (2007). New insights into the history of rice domestication. Trends in Genetics 23:578-587. https://doi.org/10.1016/j.tig.2007.08.012

Kuroki M, Saito K, Matsuba S, Yokogami N, Shimizu H, Ando I (2007). A quantitative trait locus for cold tolerance at the booting stage on rice chromosome 8. Theoretical and Applied Genetics 115:593-600. https://doi.org/10.1007/s00122-007-0589-y

Lei X, Xiao Y, Xia W, Mason AS, Yang Y, Ma Z (2014). RNA-seq analysis of oil palm under cold stress reveals a different C-repeat binding factor (CBF) mediated gene expression pattern in Elaeis guineensis compared to other species. PLoS One 9:e114482. https://doi.org/10.1371/journal.pone.0114482

Lesk C, Rowhani P, Ramankutty N (2016). Influence of extreme weather disasters on global crop production. Nature 529:84. https://doi.org/10.1038/nature16467

Li FG, Fan GY, Lu CR, Xiao GH, Zou CS, Kohel RJ, ... Wu JY (2015). Genome sequence of cultivated upland cotton (Gossypium hirsutum TM-1) provides insights into genome evolution. Nature Biotechnology 33(5):524-530. https://doi.org/10.1038/nbt.3208

Li HM, Liu SD, Ge CW, Zhang XM, Zhang SP, Chen J, ... Li Y (2019). Analysis of drought tolerance and associated traits in upland cotton at the seedling stage. International Journal of Molecular Science 20(16):3888. https://doi.org/10.3390/ijms20163888 
Li M (2014). Enrichment of statistical power for genome-wide association studies. BMC Biology 12:73. https://doi.org/10.1186/s12915-014-0073-5

Li Q, Li W, Yin D, Chang Y, Jiang H (2014). Cloning of Os01g0620100 gene and vectors construction in rice. Beijing: China Science and Technology. Available at: http://www.paper.edu.cn/releasepaper/content/201404-357

Li XL, Lu YG, Li JQ, Xu HM, Shahid MQ (2011). Strategies on sample size determination and qualitative and quantitative traits integration to construct core collection of rice (Oryza sativa). Rice Science 18:46-55. https://doi.org/10.1016/S1672-6308(11)60007-3

Li XN, Zhang XL, Zhu LM, Bu YP, Wang XF (2019). Genome-wide association study of four yield-related traits at the R6 stage in soybean. BMC Genetics 20(1):39. https://doi.org/10.1186/s12863-019-0737-9

Liu Q, Hallerman E, Peng Y, Li Y (2016). Development of Bt rice and Bt maize in China and their efficacy in target pest control. International Journal of Molecular Science 17:1561. https://doi.org/10.3390/ijms17101561

Liu Q, Zhao N, Yamaguch-Shinozaki K, Shinozaki K (2000). Regulatory role of DREB transcription factors in plant drought, salt and cold tolerance. Chinese Science Bulletin 45:970-975. https://doi.org/10.3389/fpls.2017.01049

Liu RZ, Wang BH, Guo WZ, Qin YS, Wang LG, Zhang YM, Zhang TZ (2012). Quantitative trait loci mapping for yield and its components by using two immortalized populations of a heterotic hybrid in Gossypium hirsutum L. Molecular Breeding 29(2):297-311.

Liu X, Zhao B, Zheng HJ, Hu Y, Lu G, Yang CQ, ... Zhang L (2015). Gossypium barbadense genome sequence provides insight into the evolution of extra-long staple fiber and specialized metabolites. Scientific Report 5:14139. https://doi.org/10.1038/srep14139

Liu Y, Liang J, Sun L, Yang X, Li D (2016). Group 3 LEA protein, ZmLEA3, is involved in protection from low temperature stress. Frontiers in Plant Science 7:1011. https://doi.org/10.3389/fpls.2016.01011

Lizaso J, Ruiz-Ramos M, Rodríguez L, Gabaldon-Leal C, Oliveira J, Lorite I, ... Rodríguez A (2018). Impact of high temperatures in maize: Phenology and yield components. Field Crops Research 216:129-140. https://doi.org/10.1016/j.fcr.2017.11.013

Lobell DB Bänziger M, Magorokosho C, Vivek B (2011). Nonlinear cold effects on African maize as evidenced by historical yield trials. Nature Climate Change 1:42. https://doi.org/10.1038/nclimate1043

Long SP, Ort DR (2010). More than taking the cold: Crops and global change. Current Opinion in Plant Biology 13:240247. https://doi.org/10.1016/j.pbi.2010.04.008

Lu D, Cai X, Yan F, Sun X, Wang X, Lu W (2014). Effects of high temperature after pollination on physicochemical properties of waxy maize flour during grain development. Journal of Science Food and Agriculture 94:14161421. https://doi.org/10.1002/jsfa.6433

Lü HY, Liu XF, Wei SP, Zhang YM (2011). Epistatic association mapping in homozygous crop cultivars. PLoS One 6:e17773. https://doi.org/10.1371/journal.pone.0017773

Lukatkin A (2003). Contribution of oxidative stress to the development of cold-induced damage to leaves of chillingsensitive plants: 3. Injury of cell membranes by chilling temperatures. Russian Journal of Plant Physiology 50:243-246. https://doi.org/10.1023/A:1022985500733

Lv LM, Zuo DY, Wang XF, Cheng HL, Zhang YP, Wang QL, Song GL, Ma ZY (2020). Genome-wide identification of the expansin gene family reveals that expansin genes are involved in fibre cell growth in cotton. BMC Plant Biology 20(1):223. https://doi.org/10.1186/s12870-020-02362-y

Ma Y, Dai X, Xu Y, Luo W, Zheng X, Zeng D (2015). COLD1 confers chilling tolerance in rice. Cell 160:1209-1221. https://doi.org/10.1016/j.cell.2015.01.046

Ma Z, He S, Wang X, Sun J, Zhang Y, Zhang G, Wu L, Li Z, Liu Z, Sun G (2018). Resequencing a core collection of upland cotton identifies genomic variation and loci influencing fiber quality and yield. Nature Genetics 50(6):803-813. https://doi.org/10.1038/s41588-018-0119-7

Mahar A, Amjad A, Altaf HL, Fazli W, Ronghua L, Muhammad A, ... Zengqiang Z (2020). Promising technologies for Cd-contaminated soils: drawbacks and possibilities. In: Fahad S, Hasanuzzaman M, Alam M, Ullah H,Saeed M, Khan AK, Adnan M (Eds). Environment, Climate, Plant and Vegetation Growth. Springer Publ Ltd, Springer Nature Switzerland AG, pp 63-92. https://doi.org/10.1007/978-3-030-49732-3

Mao H, Wang H, Liu S, Li Z, Yang X, Yan J (2015). A transposable element in a NAC gene is associated with drought tolerance in maize seedlings. Nature Communications 6:8326. https://doi.org/10.1038/ncomms9326

Md Jakir H, Allah B (2020). Development and applications of transplastomic plants: a way towards eco-friendly agriculture. In: Fahad S, Hasanuzzaman M, Alam M, Ullah H, Saeed M, Khan AK, Adnan M (Eds). 
Environment, Climate, Plant and Vegetation Growth. Springer Publ Ltd, Springer Nature Switzerland AG. pp 285-322. https://doi.org/10.1007/978-3-030-49732-3

Md. Enamul H, AZM Shoeb, Mallik AH, Fahad S, MM Kamruzzaman, Akib J, ... Most SS (2020). Measuring vulnerability to environmental hazards: qualitative to quantitative. In: Fahad S, Hasanuzzaman M, Alam M, Ullah H, Saeed M, Khan AK, Adnan M (Eds). Environment, Climate, Plant and Vegetation Growth. Springer Publ Ltd, Springer Nature Switzerland AG. pp 421-452. https://doi.org/10.1007/978-3-030-49732-3

Michaels SD, Amasino RM (2018). A robust method for detecting single-nucleotide changes as polymorphic markers by PCR. Plant Journal 14:381-385. https://doi.org/10.1046/j.1365-313X.1998.00123.x

Mohammad I Al-Wabel, Munir Ahmad, Adel RA Usman, Mutair Akanji, Muhammad Imran Rafique (2020a). Advances in pyrolytic technologies with improved carbon capture and storage to combat climate change. In: Fahad S, Hasanuzzaman M, Alam M, Ullah H, Saeed M, Khan AK, Adnan M (Eds). Environment, Climate, Plant and Vegetation Growth. Springer Publ Ltd, Springer Nature Switzerland AG. pp 535576. https://doi.org/10.1007/978-3-030-49732-3

Mohammad I. Al-Wabel, Abdelazeem S, Munir A, Khalid E, Adel RAU (2020b). Extent of climate change in Saudi Arabia and its impacts on agriculture: a case study from Qassim region. In: Fahad S, Hasanuzzaman M, Alam M, Ullah H, Saeed M, Khan AK, Adnan M (EdS). Environment, Climate, Plant and Vegetation Growth. Springer Publ Ltd, Springer Nature Switzerland AG. Pp 635-658. https://doi.org/10.1007/978-3-030-49732-3

Morell M, Rahman S, Regina A, Appels R, Li Z (2001). Wheat starch biosynthesis. Euphytica 119:55-58. https://doi.org/10.1023/A:1017550624902

Moser G (2015). Simultaneous discovery, estimation and prediction analysis of complex traits using a Bayesian mixture model. PLoS Genetics 11:e1004969. https://doi.org/10.1371/journal.pgen.1004969

Mubeen M, Ashfaq A, Hafiz MH, Muhammad A, Hafiz UF, Mazhar S, ... Wajid N (2020). Evaluating the climate change impact on water use efficiency of cotton-wheat in semi-arid conditions using DSSAT model. Jouranl of Water and Climate Change. https://doi.org/10.2166/wcc.2019.179/622035/jwc2019179.pdf

Muhammad N, Muqarrab A, Khurram S, Fiaz A, Fahim N, Muhammad A, ... Rahul D (2021). Kaolin and Jasmonic acid improved cotton productivity under water stress conditions. Journal of Saudi Society of Agricultural Scienes. https://doi.org/10.1016/j.sjbs.2021.07.043

Muhammad Tahir ul Qamar, Amna F, Amna B, Barira Z, Xitong Z, Ling-Ling C (2020). Effectiveness of conventional crop improvement strategies vs. omics. In: Fahad S, Hasanuzzaman M, Alam M, Ullah H, Saeed M, Khan AK, Adnan M (Eds). Environment, Climate, Plant and Vegetation Growth. Springer Publ Ltd, Springer Nature Switzerland AG. Pp 253-284. https://doi.org/10.1007/978-3-030-49732-3

Muhammad Z, Abdul MK, Abdul MS, Kenneth BM, Muhammad S, Shahen S, Ibadullah J, Fahad S (2019). Performance of Aeluropus lagopoides (mangrove grass) ecotypes, a potential turfgrass, under high saline conditions. Environment Science and Pollution Research. https://doi.org/10.1007/s11356-019-04838-3

Nazir MF, Jia Y, Ahmed H, He S, Iqbal MS, Sarfraz Z, ... Sun G (2020). Genomic insight into differentiation and selection sweeps in the improvement of upland cotton. Plants 9(6):711. https://doi.org/10.3390/plants9060711

Neiff N, Trachsel S, Valentinuz OR, Balbi CN, Andrade FH (2016). High temperatures around flowering in maize: Effects on photosynthesis and grain yield in three genotypes. Crop Science 56:2702-2712. https://doi.org/10.2135/cropsci2015.12.0755

Neild RE, Newman JE (2009). Growing season characteristics and requirements in the corn belt. Cooperative Extension Service, Iowa State University: Ames, IA, USA.

Noor M, Naveed ur R, Ajmal J, Fahad S, Muhammad A, Fazli W, Saud S, Hassan S (2020). Climate change and costal plant lives. In: Fahad S, Hasanuzzaman M, Alam M, Ullah H,Saeed M, Khan AK, Adnan M (Eds). Environment, Climate, Plant and Vegetation Growth. Springer Publ Ltd, Springer Nature Switzerland AG. pp 93108. https://doi.org/10.1007/978-3-030-49732-3

Panison F, Sangoi L, Kolling DF, Coelho CM, Md Durli MM (2016). Épocas de colheita e desempenho agronômico de híbridos de milho com ciclos de crescimento contrastantes. Acta Scientiarum Agronomy 38:219-226.

Paterson AH, Brubaker CL, Wendel JF (2013). A rapid method for extraction of cotton (Gossypium spp.) genomic DNA suitable for RFLP or PCR analysis. Plant Molecular Biology Report 11(2):122-127.

Paterson AH, Saranga Y, Menz M, Jiang CX, Wright RJ (2003). QTL analysis of genotype x environment interactions affecting cotton fiber quality. Theoretical and Applied Genetics 106(3):384-396. https://doi.org/10.1007/s00122-002-1025-y 
Pertea M, Kim D, Pertea GM, Leek JT, Salzberg SL (2016). Transcript-level expression analysis of RNA-seq experiments with HISAT StringTie and Ballgown. Nature Protocol 11(9):1650-1667. https://doi.org/10.1038/nprot.2016.095

Piepho HP, Mohring J (2007). Computing heritability and selection response from unbalanced plant breeding trials. Genetics 177:1881-1888. https://doi.org/10.1534/genetics.107.074229

Portolés S, Más P (2007). Altered oscillator function affects clock resonance and is responsible for the reduced day-length sensitivity of CKB4 overexpressing plants. Plant Journal 51(6):966-977. https://doi.org/10.1111/j.1365313X.2007.03186.x

Pugh DA, Offler CE, Talbot MJ, Ruan YL (2010). Evidence for the role of transfer cells in the evolutionary increase in seed and fiber biomass yield in cotton. Molecular Plant 3(6):1075-1086. https://doi.org/10.1093/mp/ssq054

Qamar-uz Z, Zubair A, Muhammad Y, Muhammad ZI, Abdul K, Fahad S, Safder B, Ramzani PMA, Muhammad N (2017). Zinc biofortification in rice: leveraging agriculture to moderate hidden hunger in developing countries. Archives of Agronomy and Soil Science 64:147-161. https://doi.org/10.1080/03650340.2017.1338343

Qin H, Guo W, Zhang YM, Zhang T (2008). QTL mapping of yield and fiber traits based on a four-way cross population in Gossypium hirsutum L. Theoretical and Applied Genetics 117(6):883-894. https://doi.org/10.1007/s00122-008-0828-x

Rafique S (2019). Differential expression of leaf proteome of tolerant and susceptible maize (Zea mays L.) genotypes in response to multiple abiotic stresses. Biochemistry and Cell Biology 97:581-588. https://doi.org/10.1139/bcb2018-0338

Rasheed A, Ahmed S, Wassan GM, Solangi AM, Aamer M, Khanzada H, ... Israr A (2018). Estimation of hybrid vigor for yield and yield related traits in tomato (Solanum lycopersicon MIll). International Journal of Bioscience 12(1):160-167. http://dx.doi.org/10.12692/ijb/12.1.160-167

Rasheed A, Fahad S, Aamer M, Hassan MU, Tahir MM, ...Wu Z (2020b). Role of genetic factors in regulating cadmium uptake, transport and accumulation mechanisms and quantitative trait loci mapping in rice. a review. Applied Ecology and Environmental Research 18:4005-4023. http://dx.doi.org/10.15666/aeer/1803_40054023

Rasheed A, Fahad S, Hassan MU, Tahir MM, Aamer M, ...Wu Z (2020a). A review on aluminum toxicity and quantitative trait loci mapping in rice (Oryza sativa L). Applied Ecology and Environmental Research 18:3951-3961. http://dx.doi.org/10.15666/aeer/1803_39513964

Rasheed A, Hassan M, Aamer M, Bian J, Xu Z, He X, ...Wu Z (2020c). Iron toxicity, tolerance and quantitative trait loci mapping in rice: a review. Applied Ecology and Environmental Research 18:7483-7498. http://dx.doi.org/10.15666/aeer/1803_40054023

Rasheed A, Hassan MU, Fahad S, Aamer M, Batool M, Ilyas M, ... Li H (2021a). Heavy metals stress and plants defense responses. In: Sustainable Soil and Land Management and Climate Change. CRC Press, pp 57-82.

Rasheed A, Ilyas M, Khan TN, Nawab NN, Ahmed I, Hussain MM, ... Intikhab A (2017). Genetic Association and path coefficient analysis among yield and yield related traits in tomato (Solanum lycopersicon MILL.). International Journal of Biosciences 11(5):21-26.

Rasheed A, Tahir MM, Ilyas M (2019). An investigation on genetic variability for different quantitative and qualitative traits of wheat (Triticum aestivum L) genotypes. Gomal University Journal of Research 35(1):67-74.

Rasheed A, Wassan GM, Khanzada H, Solangi AM, Han R, Li H, ... Wu Z (2021b). Identification of genomic regions at seedling related traits in response to aluminium toxicity using a new high-density genetic map in rice (Oryza sativa L.). Genetic Resources and Crop Evolution 68:1889-1903. https://doi.org/10.1007/s10722-020-01103

Rasheed A, Gill RA, Hassan MU, Mahmood A, Qari S, Zaman QU, ... Wu Z (2021c). A critical review: recent advancements in the use of CRISPR/Cas9 technology to enhance crops and alleviate global food crises. Current Issues in Molecular Biology 43:1950-1976.

Rashid M, Qaiser H, Khalid SK, Mohammad I. Al-Wabel, Zhang A, Muhammad A, ... Muhammad FQ(2020). Prospects of biochar in alkaline soils to mitigate climate change. In: Fahad S, Hasanuzzaman M, Alam M, Ullah H, Saeed M, Khan AK, Adnan M (Eds). Environment, Climate, Plant and Vegetation Growth. Springer Publ Ltd, Springer Nature Switzerland AG. Pp 133-150. https://doi.org/10.1007/978-3-030-49732-3

Raza A, Razzaq A, Mehmood SS, Zou X, Zhang X, Lv Y, Xu J (2019). Impact of climate change on crops adaptation and strategies to tackle its outcome: A review. Plants 8:34. https://doi.org/10.3390/plants8020034

Read T, Vance D (2001). Robust clustering: a comparison of SunTM Cluster 3.0 versus Sun Cluster 2.2 Software. Palo Alto, CA: Sun BluePrintsTM OnLine. 
Reeves P, Coupland G (2001). Analysis of flowering time control in Arabidopsis by comparison of double and triple mutants. Plant Physiology 126:1085-1091. https://doi.org/10.1104/pp.126.3.1085

Rehman M, Fahad S, Saleem MH, Hafeez M, Muhammad Habib ur Rahman, Liu F, Deng G (2020). Red light optimized physiological traits and enhanced the growth of ramie (Boehmeria nivea L.). Photosynthetica 58(4):922-931. https://doi.org/10.32615/ps.2020.040

Riva-Roveda L, Escale B, Giauffret C, Périlleux C (2016). Maize plants can enter a standby mode to cope with chilling stress. BMC Plant Biology 16:212. https://doi.org/10.1186/s12870-016-0909-y

Robinson MD, McCarthy DJ, Smyth GK (2010). edgeR: a Bioconductor package for differential expression analysis of digital gene expression data. Bioinformatics 26(1):139-140. https://doi.org/10.1093/bioinformatics/btp616

Ruan YL (2005). Recent advances in understanding cotton fibre and seed development. Seed Science Research 15(4):269280. https://doi.org/10.1079/SSR2005217

Ruan YL (2013). Boosting seed development as a new strategy to increase cotton fiber yield and quality. Journal of Integrative Plant Biology 55(7):572-575. https://doi.org/10.1111/jipb.12074

Rymen B, Fiorani F, Kartal F, Vandepoele K, Inzé D, Beemster GT (2007). Cold nights impair leaf growth and cell cycle progression in maize through transcriptional changes of cell cycle genes. Plant Physiology 143:1429-1438. https://doi.org/10.1104/pp.106.093948

Sabagh AE, Hossain A, Barutçular C, Iqbal MA, Islam MS, Fahad S, ... Erman M (2020). Consequences of salinity stress on the quality of crops and its mitigation strategies for sustainable crop production: an outlook of arid and semiarid regions. In: Fahad S, Hasanuzzaman M, Alam M, Ullah H, Saeed M, Khan AK, Adnan M (Eds). Environment, Climate, Plant and Vegetation Growth. Springer, Cham., pp 503534. https://doi.org/10.1007/978-3-030-49732-3

Sadam M, Muhammad Tahir ul Qamar, Ghulam M, Muhammad SK, Faiz AJ (2020). Role of biotechnology in climate resilient agriculture. In: Fahad S, Hasanuzzaman M, Alam M, Ullah H, Saeed M, Khan AK, Adnan M (Eds). Environment, Climate, Plant and Vegetation Growth. Springer Publ Ltd, Springer Nature Switzerland AG. pp 339-366. https://doi.org/10.1007/978-3-030-49732-3

Sahrish N, Shakeel A, Ghulam A, Zartash F, Sajjad H, Mukhtar A, ... Gerrit H (2022). Modeling the impact of climate warming on potato phenology. European Journal of Agronomy 132:126404.

Saito K, Hayano-Saito Y, Kuroki M, Sato Y (2010). Map-based cloning of the rice cold tolerance gene Ctb1. Plant Science 179:97-102. https://doi.org/10.1016/j.plantsci.2010.04.004

Saito K, Hayano-Saito Y, Maruyama-Funatsuki W, Sato Y, Kato A (2004). Physical mapping and putative candidate gene identification of a quantitative trait locus Ctb1 for cold tolerance at the booting stage of rice. Theoretical and Applied Genetics 109:515-522. https://doi.org/10.1007/s00122-004-1667-Z

Sajid H, Jie H, Jing H, Shakeel A, Satyabrata N, Sumera A, ... Junhua Z (2020). Rice production under climate change: adaptations and mitigating strategies. In: Fahad S, Hasanuzzaman M, Alam M, Ullah H, Saeed M, Khan AK (Eds). Environment, Climate, Plant and Vegetation Growth. Springer Publ Ltd, Springer Nature Switzerland AG. Pp 659-686. https://doi.org/10.1007/978-3-030-49732-3

Sajjad H, Muhammad M, Ashfaq A, Waseem A, Hafiz MH, Mazhar A, ... Wajid N (2019). Using GIS tools to detect the land use/land cover changes during forty years in Lodhran district of Pakistan. Environmental Science and Pollution Research. https://doi.org/10.1007/s11356-019-06072-3

Saleh J, Maftoun M (2008). Interactive effect of $\mathrm{NaCl}$ levels and zinc sources and levels on the growth and mineral composition of rice. Journal of Agricultural Sciences and Technology 10:325-336.

Saman S, Amna B, Bani A, Muhammad Tahir ul Qamar, Rana MA, Muhammad SK (2020). QTL mapping for abiotic stresses in cereals. In: Fahad S, Hasanuzzaman M, Alam M, Ullah H, Saeed M, Khan AK, Adnan M (Eds). Environment, Climate, Plant and Vegetation Growth. Springer Publ Ltd, Springer Nature Switzerland AG. pp 229-252. https://doi.org/10.1007/978-3-030-49732-3.

Sánchez B, Rasmussen A, Porter JR (2014). Temperatures and the growth and development of maize and rice: A review. Global Change Biology 20:408-417. https://doi.org/10.1111/gcb.12389

Sandhu S, Singh J, Kaur P, Gill K (2018). Cold stress in field crops: Impact and management approaches. In Advances in Crop Environment Interaction; Springer: Singapore, pp 181-204.

Sang T, Ge S (2007). Genetics and phylogenetics of rice domestication. Current Opinion in Genetics and Development 17:533-538. https://doi.org/10.1016/j.gde.2007.09.005

Saud S, Chen Y, Fahad S, Hussain S, Na L, Xin L, Alhussien SA (2016) Silicate application increases the photosynthesis and its associated metabolic activities in Kentucky bluegrass under drought stress and post-drought recovery. 
Environmental Science and Pollution Research 23(17):17647- 17655. https://doi.org/10.1007/s11356-0166957- $x$

Saud S, Chen Y, Long B, Fahad S, Sadiq A (2013). The different impact on the growth of cool season turf grass under the various conditions on salinity and drought stress. International Journal of Agricultural Science and Research 3:77-84.

Saud S, Fahad S, Cui G, Chen Y, Anwar S (2020). Determining nitrogen isotopes discrimination under drought stress on enzymatic activities, nitrogen isotope abundance and water contents of Kentucky bluegrass. Scientific Reports 10:6415. https://doi.org/10.1038/s41598-020-63548-w

Saud S, Fahad S, Yajun C, Ihsan MZ, Hammad HM, Nasim W, Amanullah Jr, Arif M and Alharby H (2017). Effects of nitrogen supply on water stress and recovery mechanisms in Kentucky Bluegrass plants. Frontiers in Plant Science 8:983. https://doi.org/10.3389/fpls.2017.00983

Saud S, Li X, Chen Y, Zhang L, Fahad S, Hussain S, Sadiq A, Chen Y (2014). Silicon application increases drought tolerance of Kentucky bluegrass by improving plant water relations and morph physiological functions. The Scientific World Journal 2014:1-10. https://doi.org/10.1155/2014/368694

Schauberger B, Archontoulis S, Arneth A, Balkovic J, Ciais P, Deryng D, ... Müller C (2017). Consistent negative response of US crops to high temperatures in observations and crop models. Nature Communications 8:13931. https://doi.org/10.1038/ncomms13931

Segura V (2012). An efficient multi-locus mixed-model approach for genome-wide association studies in structured populations. Nature Genetics 44:825-830. https://doi.org/10.1038/ng.2314

Senol C (2020). The effects of climate change on human behaviors. In: Fahad S, Hasanuzzaman M, Alam M, Ullah H, Saeed M, Khan AK, Adnan M (Eds). Environment, Climate, Plant and Vegetation Growth. Springer Publ Ltd, Springer Nature Switzerland AG. Pp 577-590. https://doi.org/10.1007/978-3-030-49732-3

Shafi MI, Adnan M, Fahad S, Fazli W, Ahsan K, Zhen Y, ... Rahul D (2020). Application of single superphosphate with humic acid improves the growth, yield and phosphorus uptake of wheat (Triticum aestivum L.) in calcareous soil. Agronomy 10:1224. https://doi.org/10.3390/agronomy10091224

Shah F, Lixiao N, Kehui C, Tariq S, Wei W, Chang C, Liyang Z, Farhan A, Fahad S, Huang J (2013). Rice grain yield and component responses to near $2^{\circ} \mathrm{C}$ of warming. Field Crop Research 157:98-110. https://doi.org/10.1016/j.fcr.2013.12.014

Shen XL, Guo WZ, Lu QX, Zhu XF, Yuan YL, Zhang TZ (2007). Genetic mapping of quantitative trait loci for fiber quality and yield trait by RIL approach in Upland cotton. Euphytica 155(3):371-380.

Shim D, Lee KJ, Lee BW (2017). Response of phenology-and yield-related traits of maize to elevated temperature in a temperate region. Crop Journal 5:305-316.

Sidra K, Javed I, Subhan D, Allah B, Syed IUSB, Fatma B, ... Rahul D (2021). Physio-chemical characterization of indigenous agricultural waste materials for the development of potting media. Journal of the Saudi Society of Agricultural Sciemces. https://doi.org/10.1016/j.sjbs.2021.08.058

Siebers MH, Slattery RA, Yendrek CR, Locke AM, Drag D, Ainsworth EA, ... Ort DR (2017). Simulated cold waves during maize reproductive stages alter reproductive growth but have no lasting effect when applied during vegetative stages. Agriculture, Ecosystems \& $\quad$ Environment 240:162-170. https://doi.org/10.1016/j.agee.2016.11.008

Song C, Li W, Pei X, Liu Y, Ren Z, He K, ... Ma X (2019). Dissection of the genetic variation and candidate genes of lint percentage by a genome-wide association study in upland cotton. Theoretical and Applied Genetics 132(7):1991-2002. https://doi.org/10.1007/s00122-019-03333-0

Steward PR, Dougill AJ, Thierfelder C, Pittelkow CM, Stringer LC, Kudzala M, Shackelford GE (2018). The adaptive capacity of maize-based conservation agriculture systems to climate stress in tropical and subtropical environments: A meta-regression of yields. Agriculture Ecosystem and Environment 251:194-202. https://doi.org/10.1016/j.agee.2017.09.019

Su J, Fan S, Li L, Wei H, Wang C, Wang H, ... Zhao S (2016). Detection of favorable QTL alleles and candidate genes for lint percentage by gwas in Chinese upland cotton. Frontiers in Plant Science 7:1576. https://doi.org/10.3389/fpls.2016.01576

Subhan D, Zafar-ul-Hye M, Fahad S, Saud S, Martin B, Tereza H, Rahul D (2020). Drought stress alleviation by ACC deaminase producing Achromobacter xylosoxidans and Enterobacter cloacae, with and without timber waste biochar in maize. Sustainability 12(6286). https://doi.org/doi:10.3390/su12156286 
Suh JP, Jeung JU, Lee JI, Choi YH, Yea JD, Virk PS (2010). Identification and analysis of QTLs controlling cold tolerance at the reproductive stage and validation of effective QTLs in cold-tolerant genotypes of rice (Oryza sativa L.). Theoretical and Applied Genetics 120:985-995. https://doi.org/10.1007/s00122-009-12268

Sun J, Zheng T, Yu J, Wu T, Wang X, Chen G, ... Wan J (2017). TSV, a putative plastidic oxidoreductase, protects rice chloroplasts from cold stress during development by interacting with plastidic thioredoxin Z. New Phytologist 215(1):240-255. https://doi.org/10.1111/nph.14482

Sun X, Liu D, Zhang X, Li W, Liu H, Hong W (2013). SLAF-seq: an efficient method of large-scale de novo SNP discovery and genotyping using high-throughput sequencing. PLoS One 8:e58700. https://doi.org/10.1371/journal.pone.0058700

Sun Z, Wang X, Liu Z, Gu Q, Zhang Y, Li Z, ... Wu L (2018). A genome-wide association study uncovers novel genomic regions and candidate genes of yield-related traits in upland cotton. Theoretical and Applied Genetics 131(11):2413-2425. https://doi.org/10.1007/s00122-018-3162-y

Tamura K, Peterson D, Peterson N, Stecher, Nei M, Kumar S (2011). MEGA5: molecular evolutionary genetics analysis using maximum likelihood, evolutionary distance, and maximum parsimony methods. Molecular Biology and Evolution 28:2731-2739. https://doi.org/10.1093/molbev/msr121

Tao S, Song G (2007). Genetics and phylogenetics of rice domestication. Current Opinion in Genetics and Development 17:533-538. https://doi.org/10.1016/j.gde.2007.09.005

Tao Z, Dong L, Ping W, Liu J (2012). Genome-wide analysis and expression profiling of the DREB transcription factor gene family in Malus under abiotic stress. Molecular Genetics and Genomics 287:423-436. https://doi.org/10.1007/s00438-012-0687-7

Tao ZQ, Chen YQ, Li C, Zou JX, Yan P, Yuan SF, Wu X, Sui P (2016). The causes and impacts for cold stress in spring maize during grain filling in the North China Plain: a review. Journal of Integrative Agriculture 15:2677-2687. https://doi.org/10.1016/S2095-3119(16)61409-0

Tariq M, Ahmad S, Fahad S, Abbas G, Hussain S, Fatima Z, ... Adnan M (2018). The impact of climate warming and crop management on phenology of sunflower-based cropping systems in Punjab, Pakistan. Agricultural and Forest Meteorology 256:270-282. https://doi.org/10.1016/j.agrformet.2018.03.015

Thakur P, Kumar S, Malik JA, Berger JD, Nayyar H (2010). Cold stress effects on reproductive development in grain crops: An overview. Environmental and Experimental Botany 67:429-443. https://doi.org/10.1016/j.envexpbot.2009.09.004

Thompson LM (2007). Weather variability, climatic change, and grain production. Science 188:535-541. https://doi.org/10.1126/science.188.4188.535

Tian B, Zhu J, Nie Y, Xu C, Meng Q, Wang P (2019). Mitigating cold and chilling stress by adjusting the sowing date of maize in the North China Plain. Journal of Agronomy Crop Science 205:77-87. https://doi.org/10.1111/jac.12299

Tian T, Liu Y, Yan H, You Q, Yi X, Du Z, Xu W, Su Z (2017). Agri GO v2.0: a GO analysis toolkit for the agricultural community, 2017 update. Nucleic Acids Research 45(W1):W122-W129. https://doi.org/10.1093/nar/gkx382

Tominaga R (2008). Arabidopsis CAPRICE-LIKE MYB 3 (CPL3) controls endoreduplication and flowering development in addition to trichome and root hair formation. Development 135:1335-1345. https://doi.org/10.1242/dev.017947

Ummenhofer CC, Meehl GA (2017). Extreme weather and climate events with ecological relevance: A review. Philos Transactions of Royal Society of Biological Sciences 372:20160135. https://doi.org/10.1098/rstb.2016.0135

Unsar Naeem-U, Muhammad R, Syed HMB, Asad S, Mirza AQ, Naeem I, ... Shafqat S (2020). Insect pests of cotton crop and management under climate change scenarios. In: Fahad S, Hasanuzzaman M, Alam M, Ullah H, Saeed M, Khan AK, Adnan M (Eds). Environment, Climate, Plant and Vegetation Growth. Springer Publ Ltd, Springer Nature Switzerland AG. pp 367-396. https://doi.org/10.1007/978-3-030-49732-3

Vos P, Hogers R, Bleeker M, Reijans M, Van de Lee T, Hornes M (2005). AFLP: a new technique for DNA fingerprinting. Nucleic Acids Research 234:4407-4414. https://doi.org/10.1093/nar/23.21.4407

Wahid F, Fahad S, Subhan D, Adnan M, Zhen Y, Saud S, ... Rahul D (2020). Sustainable management with mycorrhizae and phosphate solubilizing bacteria for enhanced phosphorus uptake in calcareous soils. Agriculture 10:334. https://doi.org/10.3390/agriculture10080334 
Wajid N, Ashfaq A, Asad A, Muhammad T, Muhammad A, Muhammad S, ... Shahzad A (2017). Radiation efficiency and nitrogen fertilizer impacts on sunflower crop in contrasting environments of Punjab, Pakistan. Environment and Science Pollution Research 25:1822-1836. https://doi. org/10.1007/s11356-017-0592-z

Wang D, Liu J, Li C, Kang H, Wang Y, Tan X (2016). Genome-wide association mapping of cold tolerance genes at the seedling stage in rice. Rice 9:61. https://doi.org/10.1186/s12284-016-0133-2

Wang M, Tu L, Lin M, Lin Z, Wang P, Yang Q, ... Zhang L (2017). Asymmetric subgenome selection and cis-regulatory divergence during cotton domestication. Nature Genetics 49(4):579-587. https://doi.org/10.1038/ng.3807

Wang M, Tu L, Yuan D, Zhu D, Shen C, Li J, ... Zhao G (2019). Reference genome sequences of two cultivated allotetraploid cottons, Gossypium hirsutum and Gossypium barbadense. Nature Genetics 51(2):224-229. https://doi.org/10.1038/s41588-018-0282-x

Wang Q, Wei J, Pan Y, Xu S (2015). An efficient empirical Bayes method for genome wide association studies. Journal of Animal Breeding and Genetics. https://doi.org/10.1111/jbg.12191

Wang R, Liu M, Yuan M, Oses-Prieto JA, Cai X, Sun Y, ... Tang W (2016). The brassinosteroid-activated BRI1 receptor kinase is switched off by dephosphorylation mediated by cytoplasm-localized PP2A B' subunits. Molecular Plant 9(1):148-157.https://doi.org/10.1016/j.molp.2015.10.007

Wang SB, Feng JY, Ren WL, Huang B, Zhou L, Wen YJ, ... Zhang YM (2016). Improving power and accuracy of genomewide association studies via a multi-locus mixed linear model methodology. Scientific Report 6:19444. https://doi.org/10.1038/srep19444

Wang X, Fan J, Xing Y, Xu G, Wang H, Deng J, ... Li Z (2019). Chapter three-the effects of mulch and nitrogen fertilizer on the soil environment of crop plants. In: Sparks DL (Ed). Advances Agronomy. Academic Press: Cambridge, MA, USA, Volume 153, pp 121-173.

Wang X, Wang H, Liu S, Ferjani A, Li J, Yan J (2016). Genetic variation in ZmVPP1 contributes to drought tolerance in maize seedlings. Nature Genetics 48:1233-1241. https://doi.org/10.1038/ng.3636

Wang Y, Tao H, Tian B, Sheng D, Xu C, Zhou H, Huang S, Wang P (2019). Flowering dynamics, pollen, and pistil contribution to grain yield in response to high temperature during maize flowering. Environmental and Experimental Botany 158:80-88. https://doi.org/10.1016/j.envexpbot.2018.11.007

Waqas MA, Khan I, Akhter MJ, Noor MA, Ashraf U (2017). Exogenous application of plant growth regulators (PGRs) induces chilling tolerance in short-duration hybrid maize. Environmental Science and Pollution Research 24:11459-11471. https://doi.org/10.1007/s11356-017-8768-0

Wattoo FM, Rana M, Fiaz S, Zafar SA, Noor MA, Hassan HM, ... Amir RM (2018). Identification of drought tolerant maize genotypes and seedling based morpho-physiological selection indices for crop improvement. Sains Malaysiana 47:295-302. http://dx.doi.org/10.17576/jsm-2018-4702-11

Wijewardana C, Henry WB, Hock MW, Reddy KR (2016). Growth and physiological trait variation among corn hybrids for cold tolerance. Canadian Journal of Plant Science 96:639-656. https://doi.org/10.1139/CJPS-2015-0286

Wu C, Kehui C, She T, Ganghua L, Shaohua W, Fahad S, ... Yanfeng D (2020). Intensified pollination and fertilization ameliorate heat injury in rice (Oryza sativa L.) during the flowering stage. Field Crops Research 252:107795.

Wu C, Tang S, Li G, Wang S, Fahad S, Ding Y (2019) Roles of phytohormone changes in the grain yield of rice plants exposed to heat: a review. PeerJ 7:e7792. https://doi.org/10.7717/peerj.7792

Xiang Y, Huang Y, Xiong L (2007). Characterization of stress-responsive cipk genes in rice for stress tolerance improvement. Plant Physiology 144:1416. https://doi.org/10.1104/pp.107.101295

$\mathrm{Xu} \mathrm{S}$ (2010). An expectation-maximization algorithm for the Lasso estimation of quantitative trait locus effects. Heredity 105:483-494. https://doi.org/10.1038/hdy.2009.180

Xu S (2013). Mapping quantitative trait loci by controlling polygenic background effects. Genetics 195:1209-1222. https://doi.org/10.1534/genetics.113.157032

Xu X, Liu X, Ge S, Jensen JD, Hu F, Li X (2012). Resequencing 50 accessions of cultivated and wild rice yields markers for identifying agronomically important genes. Nature Biotechnology 30:105-111. https://doi.org/10.1038/nbt.2050

Yamakawa H, Hirose T, Kuroda M, Yamaguchi T (2007). Comprehensive expression profiling of rice grain filling-related genes under high temperature using DNA microarray. Plant Physiology 144:258-277. https://doi.org/10.1104/pp.107.098665

Yamori W, Hikosaka K, Way DA (2014). Temperature response of photosynthesis in C3, C4, and CAM plants: Temperature acclimation and temperature adaptation. Photosynthesis Research 119:101-117. https://doi.org/10.1007/s11120-013-9874-6 
Yan C, Li X, Cheng Z, Yu H, Gu M, Zhu L (2009). Identification of QTL for cold tolerance at early seedling stage in rice (Oryza sativa) via RFLP markers. Zhongguo Shuidao Kexue 13:134-138.

Yang H, Gu Xt, Ding Mq, Lu Wp, Lu D (2019). Weakened carbon and nitrogen metabolisms under post-silking cold stress reduce the yield and dry matter accumulation in waxy maize. Journal of Integrative Agriculture 19:78-88. https://doi.org/10.1016/S2095-3119(19)62622-5

Yang H, Huang T, Ding M, Lu D, Lu W (2017). High temperature during grain filling impacts on leaf senescence in waxy maize. Agronomy Journal 109:906-916. https://doi.org/10.2134/agronj2016.08.0452

Yang Z, Zhang Z, Zhang T, Fahad S, Cui K, Nie L, Peng S, HuangJ (2017) The effect of season-long temperature increases on rice cultivars grown in the central and southern regions of China. Frontiers in Plant Science 8:1908. https://doi.org/10.3389/fpls.2017.01908

Yi N, Xu S (2008). Bayesian LASSO for quantitative trait loci mapping. Genetics 179:1045-1055. https://doi.org/10.1534/genetics.107.085589

Yu J, Pressoir G, Briggs WH, Vroh Bi I, Yamasaki M, Doebley JF (2006). A unified mixed-model method for association mapping that accounts for multiple levels of relatedness. Nature Genetics 38:203-208. https://doi.org/10.1038/ng1702

Yuan DJ, Tang ZH, Wang MJ, Gao WH, Tu LL, Jin X, ... Zhu LF (2015). The genome sequence of Sea-Island cotton (Gossypium barbadense) provides insights into the allopolyploidization and development of superior spinnable fibres. Scientific Reports 5:17662. https://doi.org/10.1038/srep17662

Zafar SA, Hameed A, Nawaz MA, Wei M, Noor MA, Hussain M (2018). Mechanisms and molecular approaches for cold tolerance in rice (Oryza sativa L.) under climate change scenario. Journal of Integrative Agriculture 17:726-738. https://doi.org/10.1016/S2095-3119(17)61718-0

Zafar SA, Patil SB, Uzair M, Fang J, Zhao J, Guo T, Yuan S, Uzair M, Luo Q Shi J (2020). Degenerated panicle and partial sterility 1 (DPS1) encodes a cystathionine beta-synthase domain containing protein required for anther cuticle and panicle development in rice. New Phytologist 225:356-375. https://doi.org/10.1111/nph.16133

Zafar-ul-Hye M, Muhammad T ahzeeb-ul-Hassan, Muhammad A, Fahad S, Martin B, Tereza D, ... Subhan D (2020b). Potential role of compost mixed biochar with rhizobacteria in mitigating lead toxicity in spinach. Scientific Reports 10:12159. https://doi.org/10.1038/s41598-020-69183-9

Zafar-ul-Hye M, Muhammad N, Subhan D, Fahad S, Rahul D, Mazhar A, ... Muhammad N (2020a). Alleviation of cadmium adverse effects by improving nutrients uptake in bitter gourd through cadmium tolerant rhizobacteria. Environment 7(54). https://doi.org/10.3390/environments7080054

Zahida Z, Hafiz FB, Zulfiqar AS, Ghulam MS, Fahad S, Muhammad RA, Hafiz MH, Wajid N, Muhammad S (2017). Effect of water management and silicon on germination, growth, phosphorus and arsenic uptake in rice. Ecotoxicology and Environmental Safety 144:11-18. https://doi.org/10.1016/j.ecoenv.2017.06.004

Zhang W, Wang J, Huang Z, Mi L, Xu K, Wu J, Fan Y, Ma S, Jiang D (2019). Effects of low temperature at booting stage on sucrose metabolism and endogenous hormone contents in winter wheat spikelet. Frontiers in Plant Sciences 10:498. https://doi.org/10.3389/fpls.2019.00498

Zhang P, Li J, Li X, Liu X, Zhao X, Lu Y (2011). Population structure and genetic diversity in a rice core collection (Oryza sativa L.) investigated with SSR markers. PLoS One 6:e27565. https://doi.org/10.1371/journal.pone.0027565

Zhang T, Hu Y, Jiang W, Fang L, Guan X, Chen J, Zhang J, Saski CA, Scheffler BE, Stelly DM (2015). Sequencing of allotetraploid cotton (Gossypium hirsutum L. acc. TM-1) provides a resource for fiber improvement. Nature Biotechnology 33(5):531-537. https://doi.org/10.1038/nbt.3207

Zhang YM, Mao Y, Xie C, Smith H, Luo L, Xu S (2005). Mapping q uantitative trait loci using naturally occurring genetic variance among commercial inbred lines of maize (Zea mays L.). Genetics 169:2267-2275. https://doi.org/10.1534/genetics.104.033217

Zhang Z (2010). Mixed linear model approach adapted for genome-wide association studies. Nature Genetics 42:355360. https://doi.org/10.1038/ng.546

Zhang Z, Li J, Pan Y, Li J, Zhou L, Shi H (2017). Natural variation in CTB4a enhances rice adaptation to cold habitats. Nature Communication 8:14788. https://doi.org/10.1038/ncomms14788

Zhang Z, Shang H, Shi Y, Huang L, Li J, Ge Q, ... Wang D (2016). Construction of a high-density genetic map by specific locus amplified fragment sequencing (SLAF-seq) and its application to Quantitative Trait Loci (QTL) analysis for boll weight in upland cotton (Gossypium hirsutum.). BMC Plant Biology 16:79. https://doi.org/10.1186/s12870-016-0741-4 
Zhang ZY, Ruan YL, Zhou N, Wang F, Guan XY, Fang L, ... Zhang TZ (2017). Suppressing a putative sterol carrier gene reduces plasmodesmal permeability and activates sucrose transporter genes during cotton fiber elongation. The Plant Cell 29(8):2027-2046. https://doi.org/10.1105/tpc.17.00358

Zhou X, Carbonetto P, Stephens M (2013). Polygenic modeling with Bayesian sparse linear mixed models. PLoS Genetics 9:e1003264. https://doi.org/10.1371/journal.pgen.1003264

Zhou X, Stephens M (2012). Genome-wide efficient mixed-model analysis for association studies. Nature Genetics 44:821-824. https://doi.org/10.1038/ng.2310

Zhu G, Gao W, Song X, Sun F, Hou S, Liu N, ... Chen Q (2020). Genome-wide association reveals genetic variation of lint yield components under salty field conditions in cotton (Gossypium hirsutum L.). BMC Plant Biology 20(1):23. https://doi.org/10.1186/s12870-019-2187-y

Zhu G, Li W, Wang G, Li L, Si Q, Cai C, Guo W (2019). Genetic basis of fiber improvement and decreased stress tolerance in cultivated versus semi-domesticated upland cotton. Frontiers in Plant Science 10:1572. https://doi.org/10.3389/fpls.2019.01572

Zia-ur-Rehman M (2020). Environment, climate change and biodiversity. In: Fahad S, Hasanuzzaman M, Alam M, Ullah H, Saeed M, Khan AK, Adnan M (Eds). Environment, Climate, Plant and Vegetation Growth. Springer Publ Ltd, Springer Nature Switzerland AG. Pp 473-502. https://doi.org/10.1007/978-3-030-49732-3
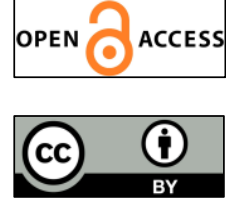

The journal offers free, immediate, and unrestricted access to peer-reviewed research and scholarly work. Users are allowed to read, download, copy, distribute, print, search, or link to the full texts of the articles, or use them for any other lawful purpose, without asking prior permission from the publisher or the author.

License - Articles published in Notulae Botanicae Horti Agrobotanici Cluj-Napoca are Open-Access, distributed under the terms and conditions of the Creative Commons Attribution (CC BY 4.0) License. (C) Articles by the authors; UASVM, Cluj-Napoca, Romania. The journal allows the author(s) to hold the copyright/to retain publishing rights without restriction. 